\title{
La historiografía hispano-hebrea
}

\author{
Enrique Cantera Montenegro *
}

\begin{abstract}
RESUMEN
ABSTRACT

En este trabajo se analiza la

In this report, the historiographic production of the Spanish Jews in the producción historiográfica de los judíos hispanos a lo largo de la Edad Media y en los primeros tiempos de la Modernidad, concretada en el cultivo de dos géneros cronísticos: las crónicas que tienen por objeto mostrar la cadena de transmisión de la tradición judía, y las crónicas que se centran eri el relato de las Middle Age and the Modern Era is analysed through the cultivation of two chronistic genders: the chronicles about the way the Jewish tradition was transmitted, and the stories about the persecutions suffered by the Jewish along the history.

persecuciones sufridas por el pueblo judio a lo largo de la historia.
\end{abstract}

\section{INTRODUCCIÓN}

Para cualquier profano en la materia que se acerque al estudio de la cultura hebrea medieval, no pasa desapercibida la escasez de escritos de carácter propiamente histórico, frente a la abundante y valiosa aportación judía a los restantes campos de la producción literaria, filosófica, teológica y científica en general. Además, los escasos escritos hebreos de contenido histórico que se han conservado de época medieval difieren considerablemente de las características que pueden considerarse como propias de los géneros historiográficos del mundo islámico medieval ${ }^{1}$, así como de las del género cronístico del Occidente cristiano.

UNED.

Son, principalmente, el género ta'rij, término con el que se denomina a la historiografía oficial islámica, consistente en relatos de contenido histórico que se inician con la creación del mundo y concluyen en la época del autor, y el género ajbar, formado por colecciones de relatos, generalmente anónimos y más o menos legendarios, y de extensión y temática variadas. 
De este modo, las civilizaciones islámica y cristiana manifestaron a lo largo de la Edad Media, y en las más diversas áreas geográficas, un especial interés por relatar por escrito los acontecimientos memorables del pasado, en ocasiones centrándose en un reino o, incluso, en una localidad determinada, y en otras ampliando el campo de interés a la historia universal, generalmente desde la creación del mundo hasta la época del autor.

Por el contrario, el judaísmo medieval postergó claramente el género historiográfico; así, desde tiempos del historiador romano de origen judío Yosef ben Mattityahu, más conocido como Flavio Josefo (Jerusalén, $c^{a}$ 37Roma, $c^{a} 100$ ), autor de obras de gran relieve como la Historia de la guerra de los judíos contra los romanos y de la ruina de Jerusalén (75-79 d.C.), en siete libros, y las Antigüedades judaicas, en veinte libros, la producción historiográfica hebrea desapareció prácticamente hasta comienzos del siglo XIX, con un breve paréntesis que comprende los últimos decenios del siglo XV y la primera mitad del siglo XVI, momento éste en el que, por las circunstancias que serán analizadas más adelante, tuvo lugar un importante renacimiento de la producción de contenido histórico. Del desprecio que buena parte de los intelectuales judíos de época medieval sintieron por el género historiográfico son buen ejemplo las palabras de Maimónides, cuando afirma que

«Los libros que encontramos entre los árabes, libros de historia, de costumbres, de reyes, del linaje de las tribus árabes, de poesía y semejantes, son libros carentes de sabiduría y de utilidad física, y representan sólo una pérdida de tiempo ${ }^{2}$.

Esta realidad resulta aún más llamativa si se tiene en cuenta que desde los tiempos bíblicos, y a lo largo de la Antigüedad clásica, los judíos dieron sobradas muestras de poseer un sentido muy desarrollado en la manera de concebir la historia, así como una decidida voluntad de perpetuar los recuerdos del pasado histórico de su pueblo. No en vano, casi la mitad de los escritos bíblicos tienen un componente propiamente histórico y, como señala el hebraísta Mariano Gaspar Remiro, es muy probable que antes incluso de que fueran redactados los libros bíblicos los hebreos fueran autores de otros diversos escritos de carácter histórico, de los que existen referencias indirectas en la Biblia; son éstos El libro de las batallas del Señor

\footnotetext{
2. Misnah con interpretación de Maimónides, Sanhedrín 10a, Jerusalem, 1965 (cita tomada de Dos crónicas hispanohebreas del siglo xv. Traducción y notas por Yolanda Moreno Koch. Introducción de Ron Barkai. Barcelona. Riopiedras Ediciones, 1992, p. 11).
} 
(Números, XXI, 14), el Libro de la rectitud o Sefer Ha-Yashar (Josué, X, 13, y /I Samuel, I, 18), las Crónicas del rey David (I Crónicas, XXVII, 24), el Libro de los hechos de Salomón (I Reyes, XI, 41), el Libro de los hechos de los reyes de Israel (II Reyes, I, 18), y la Historia del profeta Iddo (II Crónicas, XIII, 22). Junto a estos libros, parece indudable que hubo también en la misma época otros escritos, anales e historias de profetas o adivinos, utilizados también en la Biblia, pero que no se citan de forma expresa en ésta ${ }^{3}$.

Diversos autores se han interrogado acerca de las causas que pudieron motivar la escasez en la producción historiográfica hebrea desde el fin de la Antigüedad y hasta los tiempos contemporáneos, con la notable excepción del período de tránsito entre las Edades Media y Moderna. Para algunos sería la influencia del pensamiento talmúdico la que llevó a los judíos de época medieval a desinterarse por la historia contemporánea, de forma tal que redujeron su interés al modelo histórico de la Biblia ${ }^{4}$. No obstante, esta teoría parece insuficiente para explicar el abandono del género historiográfico por los judíos de la Edad Media, ya que si es cierto que el Talmud, que constituyó una referencia fundamental para el judaísmo medieval, no mostró interés por los tratados históricos, lo cierto es que la ausencia de producción historiográfica se observa también en épocas más tardías y más libies de la influencia talmúdica.

Otro autor hebreo, Amos Funkenstein, es de la opinión de que los judíos consideran que, hasta tanto no se produzca la llegada del Mesías, ellos no constituyen sujeto histórico, sino meramente objeto; por este motivo, a lo largo de la Edad Media los judíos no consideraban dignos de memoria los hechos vividos por su comunidad ${ }^{5}$. Sin embargo, se muestra menos radical en sus planteamientos que Yerushalmi y, aunque admite la escasez de la producción historiográfica hebrea en época medieval, niega de forma terminante que los judíos carecieran por entonces de conciencia histórica propiamente dicha. Así, es de la opinión de que la concepción

3 Mariano Gaspar Remiro, "Los Cronistas Hispano-Judios" (Discurso de recepción en la Real Academia de la Historia, 22 de mayo de 1920), Revista del Centro de Estudios Históricos de Granada y su Reino, X (1920), núms. 1 y 2, pp. 30-108 (en concreto, p. 37), recogiendo las palabras de Adolf Neubauer, Medieval Jewish Chronicles and Chronological Notes. Oxford, 1887-1895, 2 vols. (Reimp. en Amsterdam, Philo Press, 1970) (en concreto, vol. I, pp. V-VII).

4 Así lo afirma Yosef Hayyim Yerushalmi en su estudio titulado Zakhor, Jewish History and Jewish Memory. Washington, 1982, como señala Ron Barkai en la introducción a Dos crónicas hispanohebreas del siglo Xv', p. 11.

5 Amos FUNKENSTEIN, "Memoria colectiva y conciencia histórica", en Percepciones de la historia judía desde la antigüedad hasta el presente (en hebreo). Tel Aviv, 1991, pp. $19-25$ (citado por Ron Barkai en la introducción a Dos crónicas hispanohebreas del siglo XV, p. 12). 
histórica judía se expresa, por ejemplo, en los comentarios halájicos ${ }^{6}$, en los que son habituales los conceptos de tiempo y espacio. En este sentido, y haciendo exclusión del Sefer ha-Qabbalah de Abraham ben David (11601161), obra en la que, junto al relato acerca de la transmisión de la tradición, se incluyen anécdotas e historias relativas, principalmente, al judaísmo hispano, no cabe duda de que la Halakah constituyó la auténtica historia para los judíos hispanos de época medieval.

En sentido diferente se manifiesta otro de los grandes investigadores del judaísmo medieval, Hayyim Hillel Ben-Sasson, para quien sí es lícito hablar de una historiografía hebrea en época medieval, si bien muy distinta en sus planteamientos y en su concreción de la que por entonces elaboraban cristianos y musulmanes; para este autor, las divergencias en los planteamientos historiográficos obedecerían, principalmente, a la falta de protagonismo político de la comunidad hebrea a lo largo de toda la Edad Media ${ }^{7}$. Los planteamientos de Ben-Sasson tienen mucho fundamento, de forma que al analizar las causas que pudieron incidir en la escasez de la producción historiográfica judía en época medieval, además de las de carácter interno - principalmente la religión y la concepción teológica de la historiografía hebrea-, hay que tener en cuenta otras de carácter externo. Como acertadamente argumenta Ron Barkai, la historiografía medieval estuvo estrechamente vinculada con procesos históricos de identidad político-geográfica, lo que favoreció el desarrollo de sentimientos patrióticos que vinculan a un pueblo con un territorio, y que le confieren un destino común ligado a esas tierras. De este modo, la historiografía constituyó un instrumento de importancia fundamental para naciones que desarrollaron su existencia política sobre un territorio propio y definido; es éste el caso de España, de Francia o de Inglaterra, cuyo proceso de consolidación política en los primeros siglos de la Edad Media fue acompañado de una producción historiográfica de gran relevancia: la Historia de regibus Gothorum, Wandalorum et Sueborum de San Isidoro de Sevilla (S. VII), cuyo primer capítulo se titula, significativamente, "De laude Spaniae»; la Historia francorum de Gregorio de Tours (s. vi); y la Historia Ecclesiastica

6 De forma genérica, el concepto de Halakah comprende todo el sistema de determinaciones jurídico-religiosas, mandamientos y prohibiciones que se contienen en la Torah, así como las secciones de carácter más propiamente jurídico del Talmud, que constituyen un «corpus» de normas y formas de conducta ético-jurídicas. Asimismo se designa con este término a las decisiones finales de los rabinos, basadas en la tradición o en argumentos diversos.

7 Hayyim Hillel BEN-SASSON, «Sobre las tendencias de la cronografía judía medieval y sus pro blemas", en Continuación y cambio. Tel Aviv, 1984, pp. 379-401 (citado por Ron Barkai en la introducción a Dos crónicas hispanohebreas del siglo xv, p. 13). 
gentis anglorum de Beda el Venarble (Ss. VII-VIII), son buen ejemplo de historias nacionales ligadas a pueblos concretos y determinados. En definitiva, la falta de un territorio propio pudo ser causa fundamental del desinterés del judaísmo medieval por el género historiográfico ${ }^{8}$. En parecido sentido se manifestaba hace ya varios decenios el hebraísta Francisco Cantera Burgos quien, en la introducción a su edición española del Shébet Yehudah, afirma que la indiscutible inferioridad de la producción historiográfica hebrea de época medieval, respecto de la cristiana y la musulmana, obedece a las peculiaridades de la historia del pueblo judío y, en particular, a la diáspora, debido a que se ha considerado

«siempre eterno huésped y falto de la posesión del sentimiento de Patria, indispensable para el conocimiento de la Historia. Dispersos y vejados, entre perpetuos trabajos y persecuciones, circunstancias desfavorables y adversas al cultivo de esta disciplina» ${ }^{9}$.

$Y$ algo muy similar es lo que afirma también Abraham Aarón Newman, para quien el efecto que produjo la diáspora en el judaísmo sería el mismo que

«si un cirujano hubiese cortado el nervio histórico en el cerebro nacional» ${ }^{10}$.

Por lo tanto, para comprender y explicar en toda su amplitud la compleja panorámica de la historiografía hebrea de época medieval, resulta imprescindible tener en cuenta dos tipos de factores: uno de carácter interno, consistente en la propia concepción histórica del pueblo judío, y otro relativo a su vivencia existencial, es decir a la realidad de un pueblo que durante siglos permaneció alejado de su tierra de origen y sometido a autoridades ajenas a él. Debido a estas circunstancias particulares, el estímulo para producir literatura histórica era, necesariamente, muy diferente para los judíos que para sus contemporáneos cristianos y musulmanes, y la concepción tradicional de la Historia - en sus métodos, en su estilo literario y en su finalidad- difería considerablemente entre el judaísmo y el mundo griego.

La historia tiene para los judíos un valor cosmológico y teológico, de forma que se iniciaría con la creación del mundo y concluiría con la ins-

Dos crónicas hispanohebreas del siglo xv, introducción de Ron Barkai, pp. 14-15.

Chébet Jehuda (La Vara de Judá) de Salomón Ben Verga. Traducción española con un estudio preliminar por Francisco Cantera Burgos. Granada, 1927, p. 3.

10 Abraham A. Newman, Landmaks and Goals. Philadelphia, 1974, pp. 84-88 (citado por Ron Barkai en la introducción a Dos crónicas hispanohebreas del siglo XV, pp. 14-15). 
tauración del reino mesiánico. El historiador hebreo ofrece una visión de los acontecimientos históricos pasados y presentes que gira siempre en torno a la historia santa del "pueblo elegido de Dios", es decir de Israel; la historia de los otros pueblos sólo interesa en función de las relaciones e implicaciones que tiene con la historia judía. Del mismo modo, los acontecimientos históricos son explicados e interpretados a la luz de un fin asimismo teológico: la Redención final del pueblo de Israel, que tendrá lugar una vez pasadas diversas pruebas y padecimientos purificadores. En función de estos fines, la historiografía hebrea acoge con frecuencia leyendas y tradiciones antiguas, en muchos casos de carácter puramente fantástico, pues para el historiador judío de época medieval era menos importante la veracidad de los hechos relatados que la enseñanza que los lectores podrían extraer de ellos; lo fundamental era contribuir a la conformación de la identidad individual y colectiva del pueblo judío y, dado que vivía en un medio manifiestamente hostil, recordarle que el Dios de las generaciones precedentes seguía estrechamente unido a él, lo que le infundiría los ánimos necesarios para perseverar en sus creencias. Como de forma muy expresiva señalaba el profesor Cantera Burgos,

«El carácter de los escritos históricos judíos es diverso. Ellos no tenían príncipes para cuyo buen gobierno hubieran de anotar lo que "los príncipes antiguos ficieron"; pero tenían, en cambio, miles de correligionarios, hijos de Israel, a quienes debían fortificar en su fe. Este fin principal de fervor religioso aparece manifiesto en las crónicas e historias judaicas" ${ }^{11}$.

De este modo, teniendo en cuenta que a lo largo de la Edad Media el pueblo judío estuvo privado de independencia política y de un territorio propio que le sirviera de residencia, y que asimismo estuvo sometido con frecuencia a un régimen de inferioridad jurídica en relación a los restantes súbditos, no resulta extraño que, como señala Gaspar Remiro, la materia preferente de la historiografía hebrea medieval fuera

«el recuerdo de su tradición, la cronología de los grandes hechos de su historia antigua, gloriosos o adversos, la vida de sus Templos Santos, la lista cronológica de sus antiguos reyes, jueces y profetas, la cadena no interrumpida de los grandes hombres que conservaron en tiempo posterior su santa Ley, escrita y tradicional, la de los grandes maestros del judaísmo, y la suerte, en fin, que les era deparada en cada país de su dispersión mundial, desde que había sido destruido el estado judaico" ${ }^{12}$.

11 Chébet Jehuda (La Vara de Judá) de Salomón ben Verga, p. 4.

12 Mariano Gaspari Remiro, Op. cit., p. 43. 
Así, pues, la ruina del Estado judío tras la destrucción del Segundo Templo de Jerusalén, y el éxodo consiguiente, llevó al judaísmo a desinteresarse por el relato de los acontecimientos históricos contemporáneos; por el contrario, el recuerdo del pasado se convirtió en un imperativo ético, auténticamente sustentador de la identidad del pueblo de Israel, que debía tener permanentemente presente la alianza de Abraham con Yahveh, renovada en el Sinaí. Es claro a este respecto el mandato del Deuteronomio (XXXII, 7):

«Acuérdate de los días antiguos. Piensa en los años de tantas generaciones (oh Israel). Pregunta a tu padre y te lo dirá. Pregunta a tus ancianos y te lo dirán».

Por otra parte, si se analiza detenidamente la producción historiográfica medieval judía, es fácil comprobar cómo la mayor parte de los escritos de contenido histórico, y también la de mejor calidad, surge en momentos históricos determinados, con ocasión de acontecimientos trascendentales en la vida del pueblo judío en la diáspora. De este modo, dos de los sucesos que tuvieron más honda trascendencia histórica para el judaísmo europeo medieval, las Cruzadas y la expulsión de los judíos de España y Portugal, dieron lugar a una importante producción historiográfica; no en vano, eran sucesos que no sólo se consideraban dignos de memoria sino que, además, exigían una explicación. No debe llamar la atención, por tanto, que buena parte de la literatura histórica hebrea desde la Antigüedad hasta el siglo XIX fuera redactada por judíos españoles o de origen hispano, en los últimos decenios del siglo xv y a lo largo de la primera mitad del siglo XVI.

Esta realidad se explica también, además de por las razones expuestas hasta aquí, por los especiales lazos que unieron a los judíos españoles con Sefarad, de forma que ninguria de las diásporas judías acaecidas en otras diversas áreas geográficas europeas generó un sentimiento de recuerdo tal hacia la tierra que se veían obligados a dejar como el que manifestaron los judíos sefardíes; este sentimiento tiene su mejor expresión no sólo en la producción historiográfica sino también en las composiciones poéticas, y responde a una doble motivación: al orgullo del origen hispano, en el convencimiento de la superioridad teológica y cultural del judaísmo sefardí sobre el ashkenazí, y al indudable apego que sentían hacia la tierra en la que habían nacido ellos o sus antepasados inmediztos.

En definitiva, en la diáspora de los judíos españoles y portugueses a fines del siglo XV hay que buscar la raíz de los primeros escritos hebreos de carácter propiamente histórico desde los tiempos de Flavio Josefo. De 
este modo, de los ocho autores judíos de crónicas históricas en el siglo XVI, cinco son exiliados o hijos de exiliados de España y Portugal: Salomón ben Verga, Abraham Zacut, Samuel Usque, Yosef ha-Kohén y Gedallia ben Yosef ibn Yahyá, de Ímola; otro, el cretense Eliyahu Capsali, estuvo muy influido por los exiliados españoles que llegaron a esta isla mediterránea; y sólo dos, el italiano Azariah min ha-Edomim y el alemán David Ganz, pertenecían a un círculo cultural no hispano, si bien este último, que escribió a fines del siglo XVI, conocía las crónicas escritas por autores hispanos ${ }^{13}$.

Analizada en sentido amplio, la historiografía hispano-hebrea comprende, básicamente, dos tipos de géneros, en cuanto al estilo literario y a la finalidad que los impulsa:

a) Uno es el que engloba las obras cuyos autores, a quienes cabría denominar "cronistas de la tradición judía», tienen como objetivo fundamental mostrar la perpetuación a través de los tiempos de la Ley mosaica, escrita y oral, así como la transmisión de la tradición de generación en generación. Se trata de escritos, por tanto, cuyo carácter es casi más religioso que propiamente histórico, y en los que sólo de forma ocasional hay referencias a la historia política. Su interés era extraordinario para los pensadores judíos de la Edad Media, principalmente para los exégetas de la Torah y del Talmud, para los teólogos y para los filósofos, para quienes era imprescindible referirse a una tradición escrita y oral que fuera fiable. Por este motivo, a lo largo de la Edad Media las crónicas acerca de la transmisión de la tradición (Sefer ha-Qabbalah) y los libros de genealogía (Sefer Yuhasin) ocuparon un lugar relevante en la literatura hebrea.

A este género pertenecen el Sefer ha-Qabbalah de Abraham ben David, el Sefer ha-Qabbalah de Abraham ben Salomón de Torrutiel, el capítulo 50 del Qissur zeker Saddiq de Rabí Yosef ben Saddiq de Arévalo, el Ma'amar 'al séder ha-dorot de Seadyah ibn Danan, y el Sefer Yuhasín de Abraham Zacut.

Aunque no se trate de una obra propiamente histórica, podría ser citado aquí también el Sefer ha-yasar, obra del siglo XII consistente en una colección de leyendas y haggadás, que abarca desde Adán hasta Josué, y cuya finalidad consiste en familiarizar a la comunidad hebrea con la historia bíblica. Pese a que se trata de una obra anónima, es lícito suponer que fuera

13 Yosef Hayyim Yerushalmi, Zakhor, p. 80 (citado por Ron Barkai en la introducción a Dos crónicas hispanohebreas del siglo Xv, p. 16). 
redactada en España, teniendo en cuenta no sólo el conocimiento que demuestra tener el autor de la lengua árabe, sino también por la terminología empleada, habitual en la literatura sefardí de la época.

b) Otro género historiográfico, cuya finalidad última es asimismo religiosa, es aquél en el que pueden ser enmarcadas las obras que tienen por objeto relatar de forma detallada las persecuciones y aflicciones que padecieron los judíos a lo largo de la historia, con el fin de reforzarles en la fe y propiciar los sentimientos de unidad y solidaridad entre ellos. El mensaje fundamental que subyace en estas obras es que las persecuciones eran la consecuencia del relajamiento en la observancia de la Ley; pero lo mismo que en el pasado el pueblo judío había superado las duras pruebas de la persecución, también se superarían las que se sufrían en su tiempo.

Ya en la Plena Edad Media fueron redactados algunos informes acerca de las persecuciones sufridas por los judíos que residían en diversas localidades alemanas de la cuenca del Rhin con ocasión de las expediciones organizadas para las primeras Cruzadas. Si algunos de estos informes son anónimos, otros son de autor conocido, como el de Rabí Eliezer ben Nathan de Mainz sobre las persecuciones antijudías acaecidas en los prolegómenos de la primera cruzada, o los de Eliezer ben Yishaq de Worms y Efraín ben Jacob de Bonn acerca de las que tuvieron lugar en los momentos previos a la segunda cruzada ${ }^{14}$.

Contemporáneos de estos tratados son unos «libros de memoria»o "de recordación», es decir unos martirologios, en los que se registran los nombres de judíos muertos por su fe, con indicación de las localidades en las que se había producido su martirio. Como señala Adolf Neubauer, parece muy probable que este tipo de escritos se conservaran en las más importantes comunidades judías europeas, con la finalidad de proceder a su lectura en las sinagogas en las oraciones públicas por los difuntos ${ }^{15}$.

Utilizando los informes acerca de persecuciones concretas sufridas por los judíos en diversas localidades y los martirologios, se formaron unas compilaciones generales en las que, de forma más o menos ordenada y más o menos completa, se anotaban las persecuciones, las violencias en la

\footnotetext{
${ }^{14}$ Una excelente síntesis acerca de las consecuencias que las expedicirnes organizadas con motivo de las primeras Cruzadas tuvieron para las comunidades judías de la Europa occidental y central en Fernando SUAREZ BILBAO, "Los judíos y las Cruzadas. Las consecuencias y su situación jurídica", en Medievalismo, año 6, núm. 6 (Madrid, 1996), pp. 121-146, y año 7, núm. 7 (Madrid, 1997), pp. 41-75.

15 Adolf Neubauer, Medieval Jewish Chronicles and Cronological Notes. Oxford, 1887-1895.
} 
fe y las calamidades padecidas por los judíos desde los tiempos históricos más remotos. A este género pertenece la crónica titulada Ma'amar Zikrón ha-shemadot (Recuerdo de persecuciones) de Profiat Durán (Yishaq ben Mosheh ha-Levi o Efodi) de Perpiñán, famoso apologeta hispano-hebreo de la segunda mitad del siglo XIV (?-1414), y de la que únicamente se conservan algunas referencias indirectas, como las que hace Yishaq Abravanel en su Yeshu'ot meshiho (II, 22), obra exegética de contenido mesiánico; en ella se relacionan los mártires judíos desde la destrucción del Segundo Templo de Jerusalén ${ }^{16}$.

Pero además de esta crónica, lamentablemente perdida, pertenecen también a este género las obras tituladas Emeq ha-Bakha (El valle del Ilanto), de Yosef ha-Kohén, y Shebet Yehudah (La vara de Judá), de Salomón ben Verga, no sólo la obra más completa de esta forma de hacer historia sino también, en opinión de Isidore Loeb, la más original y la más viva de toda la historiografía hebrea de épocas medieval y moderna ${ }^{17}$.

Al margen de los autores reseñados anteriormente, y a los que se hará referencia más detallada a lo largo de este trabajo, cabe citar asimismo entre los cultivadores del género histórico a dos judíos españoles del siglo XIV, cuya producción no alcanzó, sin embargo, la misma notoriedad:

- Mosheh ben Yishaq ibn Waqar, quien el día primero del mes de elul (septiembre/octubre) del año 1340 concluyó en Guadalajara un tratado de retórica titulado Imre no'am (Dichos placenteros), compuesto a base de versículos bíblicos, y el opúsculo Ner Yisra'el (Antorcha de Israel), en el que se trata acerca de las guerras que asolaron al país y de las penas y aflicciones del judaísmo ${ }^{18}$.

- Yosef ibn Waqar, médico de la corte del rey Enrique II de Castilla, y enviado en misión diplomática a Granada. Es autor de una versión árabe compendiada de la Estoria de España de Alfonso X el Sabio, escrita con el fin de que sirviera a un sabio musulmán para la redacción de una historia de España ${ }^{19}$.

16 Chébet Jehuda (La Vara de Judá) de Salomón ben Verga, p. 5.

17 Isidore LOEB, "Le folklore juif dans la chronique du Schebet Jehuda d'ibn Verga", en Revue des Études Juives, XXIV (1892), pp. 1-29.

18 Yitzhak BAER, Historia de los judios en la España cristiana. Madrid. Altalena, 1981, 2 vols (vol. II, p. 731, nota 53).

19 M.M. ANTUÑA, "Una versión árabe compendiada de la "Estoria de España" de Alfonso el Sabio", en Al-Andalus, I (1933), pp. 105-154 (citado por Yitzhak BAER, Historia de los judios en la España cristiana, II, p. 733, nota 67 ). 


\section{LA CRONOLOGIA HISPANO-HEBREA: LOS «CRONISTAS DE LA TRADICIÓN JUDÍA»}

En este apartado serán analizadas las obras de la literatura hispanohebrea que tienen por objeto estudiar la transmisión de la tradición judía de generación en generación: son el Sefer ha-Qabbalah (Libro de la Tradición) de Abraham ben David, el Sefer ha-Qabbalah (Libro de la Tradición) de Abraham ben Salomón de Torrutiel, el capítulo 50 del Qissur zeker Saddiq (Compendio de la memoria del justo) de Rabí Yosef ben Saddiq de Arévalo, el Sefer Yuhasín (Libro de los Linajes) de Abraham Zacut, y el Ma'amar 'al séder ha-dorot (Tratado sobre la sucesión de las generaciones) del granadino Seadyah ibn Danan.

\subsection{El Sefer ha-Qabbalah (Libro de la Tradición) de Abraham ben David}

\subsubsection{El autor}

Rabí Abraham ben David ha-Leví ibn Daud (o ben David) de Toledo puede ser considerado, propiamente, el primer historiador hispano-hebreo. Aunque en su obra ha dejado muy pocos datos que permitan reconstruir su biografía, es generalmente admitido que nació en Toledo, en torno al año 1110 , en el seno de una familia que, por línea materna, alcanzó una considerable notoriedad en el mundo de la cultura. Nieto de Yishaq ben Baruk ben al-Baliah, astrólogo del rey al-Mutamid de Sevilla y nasi ${ }^{20}$ de todas las comunidades judías de la taifa sevillana, se trasladó de niño a la ciudad de Córdoba, donde recibió una sólida formación intelectual bajo la dirección de su tío materno Rabí Baruk ben Yishaq al-Baliah, una importante autoridad rabínica y eminente talmudista y filósofo. A lo largo de su vida, Abraham ben David alcanzó gran notoriedad como astrónomo, filósofo e historiador, y es probable que estudiara también medicina, ya que en su tratado filosófico Ha-emunah ha-ramah (La fe sublime) demuestra conocimientos anatómicos.

En el año 1149, tras la toma de Córdoba por los almohades, huyó a Toledo, ciudad donde falleció en el año 1180, según se dice en algunas

20 Literalmente, «príncipe», «patriarca». En época medieval se daba el título de nasí a los jefes de las comunidades judías, con un significado político variable, aunque casi siempre como título meramente honorífico. 
fuentes hebreas por causa de su fe ${ }^{21}$. Jaime Bages es de la opinión de que su muerte tendría lugar durante un motín antijudío, cuya naturaleza resulta desconocida ${ }^{22}$. Su imagen de hombre erudito y piadoso se vio reforzada en buena medida por su muerte como mártir.

Su producción literaria es muy variada, pero sobresale en los campos de la filosofía y de la historia apologética. Abraham ben Salomón de Torrutiel se refiere asimismo a una obra de carácter astronómico escrita por Abraham ben David, pero lo cierto es que nada seguro se sabe de ella. Su aportación en el terreno de la filosofía es de importancia, ya que su obra más destacada, Ha-emunah ha-ramah (La fe sublime), consiste en el primer tratado aristotélico en la historia de la filosofía judía; escrita inicialmente en árabe, sólo a fines del siglo XIV fue traducida al hebreo. Pese a su aristotelismo, ben David manifiesta en todo momento una voluntad decidida por armonizar religión y tilosofía, convencido de que la auténtica filosofía no se opone a los principios de la Ley. Su esfuerzo se orienta a presentar un judaísmo racional, en armonía con la filosofía, y a definir de forma precisa los deberes religiosos de los judíos.

Pero la obra por la que Abraham ben David es más conocido es, sin duda alguna, por su Sefer ha-Qabbalah (Libro de la Tradición), que está considerada como una de las obras cumbres de la cronología judía. Escrita en hebreo en el año judío 4921 (1160-1161), en adelante fue profusamente utilizada por los más diversos historiadores hebreos.

\subsubsection{Finalidad y estructura general del Sefer ha-Qabbalah}

Pese a que el contenido del libro es propiamente histórico, su finalidad es eminentemente apologética. En su primer capítulo, Abraham ben David expone con claridad los propósitos que le guian para la redacción de su obra:

«Escribimos este tratado de la tradición para dar a conocer a los discípulos que todas las palabras de nuestros maestros, de bendita memoria, los sabios de la Misnah y del Talmud, fueron transmitidas a un sabio grande $y$

21 Así lo indican Abraham ben Salomón de Torrutiel en su Sefer ha-Qabbalah (capítulo 1), Rabí Yosef ben Saddiq de Arévalo en el capítulo 50 de su Qissur zeker Saddiq, y Abraham Zacut en su Sefer Yuhasín. Salomón ben Verga afirma en el Shebet Yehudah (capítulo 5) que murió ahorcado por orden del rey Alfonso VIII, por "santificar al Nombre" y por no renegar de la Ley.

22 Abraham Ben David, Sefer ha-Kabbalah (Libro de la Tradición). Traducción por Jaime Bages. Valencia. Anúbar, 1972, p. 12. 
justo por otro, a un presidente de la Academia y su grupo por otro, así hasta los miembros de la Gran Asamblea que las recibieron de los profetas, ¡bendita sea la memoria de todos ellos!

Los sabios del Talmud y los de la Misnah no dijeron nada de su propia invención, ni siquiera la cosa más pequeña, excepto las correcciones que hicieron con el respaldo de todos con el fin de construir una valla a la Torah. Si un hombre de espíritu herético pretende arrojar oscuridad sobre esto diciendo 'yo dudo de sus palabras porque entre ellos están divididos en varios pasajes', tú advertirás su torpeza y le harás saber que es 'un rebelde según el tribunal' y que los rabinos, de bendita memoria, nunca estuvieron divididos en lo fundamental de cada mandamiento, sólo en su desarrollo. Ellos escucharon lo fundamental a sus maestros y no les preguntaron por su desarrollo porque no profundizaron todo lo necesario. Así, no se dividieron en la cuestión de encender o no la lámpara de sabat, sólo en con qué se encendía y con qué no. De forma análoga, estaban de acuerdo en leer el semá de la tarde y de la madrugada y estaban divididos en cuanto al momento preciso en que se leía el semá de la tarde y el de la madrugada. Y de este modo ocurre con todas sus palabras» ${ }^{23}$.

En definitiva, ben David pretendía demostrar el origen divino de la Ley oral, recibida por Moisés en el monte Sinaí junto con la Ley escrita, y su transmisión fiel de generación en generación, hasta los maestros de su tiempo. De este modo, trataba de desvirtuar las acusaciones de los caraítas de que la Ley oral era una mera invención de los rabanitas. El caraísmo es una herejía surgida en el seno del judaísmo; nacida en Babilonia a mediados del siglo VIII, se extendió seguidamente a Palestina, convirtiéndose Jerusalén en su centro espiritual. A partir del siglo Ix el caraísmo conoció una considerable expansión, en particular por el imperio bizantino, donde se formó una importante comunidad caraíta, así como por Persia, Siria, Egipto, el norte de África y la Península Ibérica ${ }^{24}$. El caraísmo atacaba los cimientos mismos de la tradición judía, propugnando la exclusiva validez de la Ley escrita y negando, por tanto, cualquier valor a las enseñanzas de la Mishnah y del Talmud ${ }^{25}$; para ellos, el Talmud había desnaturalizado el judaísmo, por lo que defendían un retorno de la religión al texto de la Escritura. Como quiera que habían sido las autoridades rabínicas quienes

23 Abraham IBN Daud, Libro de la Tradición (Sefer ha-Qabbalah). Introducción, traducción y notas por Lola Ferré. Barcelona. Riopiedras Ediciones, 1990, pp. 39-40.

24 La presencia caraíta en los reinos hispanos no fue, sin embargo, especialmente relevante; su mayor fuerza la alcanzaron en algunas comunidades judías de la meseta norte, como Carrión - Burgos, pero fueron combatidos por el propio rey Alfonso VII, quizás temeroso de que los rabinos perdieran el control de la comunidad hebrea, o por la influencia de Yehudah ben Ezra, consejero del monarca y uno de los más firmes opositores al caraísmo. A fines del siglo xll el caraísmo habia desaparecido prácticamente de todas las comunidades judías europeas.

25 De ahí su nombre de caraítas, es decir «discípulos de la Escritura». 
llevaron a cabo la compilación de la Ley oral y su imposición como norma legal, los caraítas les negaban toda autoridad religiosa, lo que ponía en serio peligro los cimientos mismos sobre los que se asentaba el judaísmo.

En estas circunstancias, era de fundamental importancia para el rabinismo demostrar de forma fehaciente que la Ley oral era también de procedencia divina, equiparándola en sus orígenes a la Ley escrita. Para ello, Abraham ben David recurre al método de la «cadena de transmisión de la Ley", utilizado ya en el tratado Pirqué Abot de la Mishnah; esta cadena se iniciaría con Moisés, quien recibió el Decálogo y otra Ley oral complementaria durante los cuarenta días que permaneció en el monte Sinaí, y proseguiría, sucesivamente, con Josué, los varones viejos, los profetas y los varones de la Gran Sinagoga:

«Moisés, nuestro maestro, con él sea la paz, recibió la Ley del Sinaí, con sus diez mandamientos, en nisán del año 2449 y los otros mandamientos en los cuarenta días que permaneció en el monte, hasta el día diecisiete de tamuz, en que bajó y rompió las tablas... Josué, hijo de Nun, fuente de la sabiduría, recibió de Moisés la Ley Escrita y la Ley Oral... A su vez Josué las transmitió a los ancianos y pasó a la vida eterna en el año 2517. Los ancianos que le sobrevivieron las transmitieron a los profetas y los profetas las transmitieron entre ellos, de una generación a otra, hasta Hagay, Zacarías y Malaquías. Los profetas las transmitieron a los miembros de la Gran Asamblea y éstos a Zorobabel, hijo de Sealtiel, hijo de Jeconías, rey de Judá y a los que venían con Zorobabel: Yesuá, Nehemías, Serayah, Relatah, Mordekay, Bilsán, Mispar, Bigvay, Rehum, Baanah, ellos son los miembros de la Gran Asamblea” ${ }^{26}$.

Seguidamente ben David fija la cronología de los hechos históricos más relevantes de la historia del pueblo de Israel, haciendo siempre especial hincapié en la transmisión de la tradición. A este fin, distribuye su relato cronístico en varios capítulos, dedicados a las diferentes generaciones de transmisores de la Ley oral: Tannaim, Amoraim, Saboraim, Gaonim y Rabbanim. Pese a que esta división es puramente artificial, en la actualidad sigue utilizándose para distinguir entre los principales grupos de líderes rabínicos. El séptimo y último capítulo está dedicado a la transmisión de la tradición desde las Academias de Babilonia a al-Andalus, que ben David explica mediante la leyenda, muy popular, de los cuatro sabios babilonios cautivos; dos de estos sabios habrían sido vendidos en Córdoba como esclavos, lo que permitió la transmisión de la tradición a esta ciudad andalusí ${ }^{27}$ :

26 Abraham IBN Daud, Libro de la Tradición, pp. 43-45.

27 Uno de estos dos sabios sería Mosheh ben Hanok (?-965), apresado tras salir de Bari, y vendido y rescatado en Córdoba. Independientemente de la veracidad histórica del relato de 
«Antes de esto sucedió que Yahveh desposeyó a las academias de los ingresos que les llegaban desde España, el Magreb, África, Egipto y Tierra Santa.

Esto fue lo que ocurrió: salió de la ciudad de Córdoba un capitán designado para la flota, su nombre era Ibn Rumajis; lo enviaba un rey ismaelita de España, Abd al-Rajmán al-Naser, y fue el designado para la poderosa flota con el fin de conquistar los barcos cristianos y las ciudades costeras.

Fueron hasta la costa de Israel, rodearon el mar de Grecia y sus islas y encontraron un barco. En él viajaban cuatro grandes sabios, que iban desde la ciudad de Bari hasta otra llamada Sefastin, se dirigían a la reunión de Kalla. Conquistó Ibn Rumajis el barco y apresó a los sabios: R. Hosiel, padre de Rabenu Jananel; otro R. Moseh, al que detuvieron con su mujer e hijo, R. Janoq, que era aún un muchacho; el tercero, R. Semariah ben R. Eljanán; del cuarto ignoro su nombre.

Intentó el capitán forzar y violar a la mujer de R. Moseh porque era muy hermosa, ella gritó a R. Moseh, su marido, en lengua santa y le preguntó si los ahogados en el mar resucitaban, y él respondió: 'Dijo Yahveh: Yo sacaré de las profundidades del mar' (Sal. 68,23 ). Cuando oyó que resucitaría, se arrojó al mar y se ahogó.

Estos sabios no hablaron con nadie sobre su virtud ni su sabiduría. El capitán vendió a R. Semariah en Alejandría de Egipto. Desde allí subió a Fustat y fue presidente. A R. Hosiel lo vendió en África, en la costa, y desde allí subió a Kairuán, que en estos tiempos era la ciudad ismaelita más importante de todo el Magreb. Allí R. Hosiel fue presidente y nació su hijo Rabenu Jananel.

Llegó el capitán a Córdoba y vendió allí a R. Moseh y R. Janoq, su hijo, y los rescataron los hombres de Córdoba, que creyeron que eran gente del pueblo. Había en Córdoba una sinagoga llamada Sinagoga del Midrás y un juez llamado R. Natán que era piadoso y grande. Pero los sefarditas no estaban instruidos en las palabras de nuestros maestros, de bendita memoria, pese a lo cual, con lo poco que sabían hacían comentarios e interpretaciones, más o menos correctas.

En cierta ocasión R. Natán el juez comentaba 'La sumersión', tema del tratado de Yoma y no sabía interpretarlo. Estaba sentado R. Moseh en un rincón como un asistente más y le dijo a R. Natán: 'Maestro, así habrá demasiadas sumersiones'. Cuando escuchó el juez y los discípulos sus palabras se sorprendieron y le pidieron que interpretase para ellos la halakah y lo hizo debidamente y cada uno le hacía preguntas sobre las dudas que tenía, ordenaron sus preguntas y él fue respondiendo la mayoría con sabiduría.

\footnotetext{
Abraham ben David, lo cierto es que Mosheh ben Hanok llegó a ejercer como daj yán, juez y líder espiritual de la comunidad de Córdoba a mediados del siglo $x$. Sus amplios conocimientos jurídicos servirían de base a Hasday ibn Shaprut en su proyecto de reforzamiento de la autonomía del judaísmo andalusí con respecto a las academias babilónicas (Ángel SÁENz-BADILLOS y Judit TARGarona Borrás, Diccionario de autores judíos (Sefarad. Siglos $x$-xV). Córdoba. Ediciones EI Almendro, 1988, p. 71).
} 
Fuera había litigantes que no tenían derecho a entrar hasta que terminasen los discípulos su lección. Ese mismo día salió R. Natán el juez, le siguieron los litigantes y él les dijo: 'Yo ya no soy el juez, pero este hombre que viste saco y es un viajero es mi maestro y yo seré su discipulo desde hoy mismo y vosotros debéis nombrarlo juez de la comunidad de Córdoba: Así lo hicieron, le pusieron una gran asignación, lo honraron con vestiduras exquisitas y con una montura» ${ }^{28}$.

Este capítulo séptimo resulta especialmente interesante para la historia del judaísmo andalusí, por cuanto en él se hace referencia a algunas de las más destacadas figuras hebreas de al-Andalus, con curiosas noticias acerca de la vida de los judíos en las cortes cordobesa y granadina. En relación con los seis capítulos anteriores, en éste se observan más apreciaciones de carácter personal y mayor entusiamo por parte del autor, siendo más frecuente la inclusión de anécdotas sobre los diversos personajes citados, lo que obedece, sin duda, a que se trata de personas y de acontecimientos que conocía directamente. Por todo ello, este capítulo constituye una fuente de fundamental importancia para la historia del judaísmo andalusí en los siglos $\mathrm{x}$ al XII, en particular por lo que se refiere al mundo de la cultura.

En el epílogo, Abraham ben David expone nuevamente el objeto de su obra, ataca con firmeza a los caraítas por haberse apartado de la tradición, y elogia a los rabanitas, «fieles testigos que hablan por boca de fieles testigos». Relata a continuación cómo llegó la herejía caraíta a Sefarad, y la expansión que conoció en tierras hispanas hasta que fue definitivamente erradicada. Se refiere nuevamente a las más destacadas personalidades del judaísmo andalusí, así como a las circunstancias que motivaron el exilio de numerosos judíos desde al-Andalus a los reinos cristianos del norte de la Península lbérica tras la invasión almohade, valorando muy positivamente la acogida que se les prestó en la España cristiana; quizás por este motivo - y por su firme actitud frente al caraísmo-, ben David se muestra particularmente favorable hacia la figura del rey Alfonso VII:

«Tras su fallecimiento ${ }^{29}$ brotó con virulencia el odio de estos heréticos - los caraítas - hasta que reinó Don Alfonso, hijo de Raimundo, rey de reyes, el Emperador. En su reinado hubo patriarcas que ocuparon el lugar de sus antepasados y los expulsaron.

28 Abraham IBn Daud, Libro de la Tradición, pp. 83-85.

29 Se refiere a Rabí Yosef ha-Nasí ben Ferruziel, más conocido como Cidiello, personaje que alcanzó gran notoriedad en la corte de Alfonso VII como médico y consejero. Es citado, además de por Abraham ben David, por don Rodrigo Jiménez de Rada en su De rebus in Hispania gestis. 
Así ocurrió la expulsión de los heréticos en Castilla: Don Alfonso, hijo de Raimundo, rey de reyes, reinó con justicia e impuso su poder sobre todos los ismaelitas que se encontraban en España y les puso un impuesto. $Y$ en su propio reino 'Yahveh le concedió descanso respecto a todos los enemigos de su entorno' (II Sa. 7,1$)$. El rey estuvo sobre Edom ${ }^{30}$ treinta y cinco años. En la medida en que se fortalecía el reino bajo su poder arrebató a los ismaelitas muchas atalayas que estaban o sobre caminos del país ismaelita o sobre el país de Edom» ${ }^{31}$.

El epílogo concluye con el anuncio por parte del autor de su propósito de redactar dos tratados de contenido histórico, proyecto que llevó a cabo algún tiempo después. Uno de ellos consiste en una breve historia cronológica de Roma, titulada Zikron dibre Romi (Historia de los hechos de Roma), que abarca desde la fundación de la ciudad hasta la conversión de Recaredo al catolicismo. Para la redacción de esta obra Abraham ben David se basa, principalmente, en fuentes árabes e hispano-cristianas, y su objetivo fundamental consiste en demostrar que los Evangelios se habrian redactado más tardíamente de lo que se suponía, con lo que perderían todo su valor histórico en relación con la figura de Jesucristo; se trata, por tanto, de una obra con un claro objetivo anticristiano, en la que se llega a acusar al cristianismo de ser una invención de tiempos de Constantino.

El otro tratado consiste en una historia de los reyes de Israel durante el Segundo Templo, titulada Zikron dibre malke Yisra'el be-bayit sheni (Historia de los hechos de los reyes de Israel durante el Segundo Templo), cuyo objetivo consiste en demostrar que no todas las profecías se cumplieron en ese tiempo. En esta obra, en la que se ataca duramente a los saduceos, considerados precursores de los caraítas, Abraham ben David se muestra muy poco original, siguiendo muy de cerca el Sefer Yosippon (Libro de José), una historia del pueblo judío durante el período del Segundo Templo, cuyo autor es un judío italiano o siciliano del siglo $\mathrm{x}$, identificado con frecuencia con Yosef ben Gorión, si bien algunas adiciones son atribuidas a Jerahmeel ben Salomón; el Sefer Yosippon se considera por parte de algunos autores una adaptación hebrea tardía de la obra historiográfica de Flavio Josefo.

No obstante, y en conjunto, estos dos tratados carecen de cualquier interés histórico ${ }^{32}$.

30 El término Edom se utiliza desde la época talmúdica para designar, de forma simbólica, a Roma y a su imperio sobre todo el mundo. En la Edad Media se denomina de esta forma, genéricamente, a la Cristiandad.

31 Abraham IBN Daud, Libro de la Tradición, p. 104.

32 Mariano GASPAR REMIRO, "Los cronistas hispano-judíos», p. 55. 


\subsubsection{Fuentes, estilo literario y concepción histórica del Sefer ha-Qabbalah}

En la redacción de su obra, Abraham ben David hizo uso de un complejo y diversificado conjunto de fuentes, principalmente de los diversos libros bíblicos y de la Mishnah, en particular de su tratado Abot. Asimismo utilizó frecuentemente dos importantes crónicas hebreas antiguas: a) El Seder Olam Rabbah (Gran Orden del Mundo), obra atribuida a Rabí Yosef ben Halafta, tanna de la tercera generación (hacia el año 160 d.C.) a quien se considera autor del tratado talmúdico de Kélim (utensilios); se trata de una figura de extraordinaria importancia, un halakista de relieve que enseñaba en Seforis, y que es citado más de trescientas treinta veces por la Mishnah. Su crónica abarca desde la creación del mundo hasta la revuelta de Bar Kokbá (132-135 d.C.), siendo en la segunda parte del último capítulo, que comprende desde Alejandro Magno hasta Bar Kokbá, donde se ofrecen los datos más interesantes. Y b) El Seder Olam Zutah (Pequeño Orden del Mundo), obra en la que se recoge una lista de ochenta generaciones desde Abraham hasta la partida para el exilio y el período talmúdico. Se interesa sobre todo por las funciones del exilarca, señalando su ascendencia davídica; los otros exilarcas, que no podían alegar tal linaje, carecerían para el autor de legitimidad ${ }^{33}$. Del mismo modo, es muy probable que empleara otras diversas obras hebreas de época medieval, como El Libro de Adam; el Orden de los Tannaim y Amoraim (Seder Tanna'im we-amora'im), del siglo Ix; la célebre Epístola de Rabi Sherirah, Gaón, redactada en torno al año 980; y los escritos del andalusí Rabí Samuel ibn Nagrella (993-1055) ${ }^{34}$.

Por lo que se refiere a su estilo literario, los relatos incluidos en el Sefer ha-Qabbalah son, por regla general, muy concisos, y su redacción fluida y sencilla, a base de frases breves, alcanzando en algunos pasajes gran brillantez.

Por otra parte, la información facilitada por Abraham ben David en su crónica es bastante fiable cuando narra acontecimientos contemporáneos o no muy lejanos en el tiempo, en tanto que cuando se trata de sucesos remotos es fácil apreciar errores históricos, pese a que no cabe ninguna duda de que el autor se esfuerza por mantener en todo momento la veracidad de su relato. Sólo se deja llevar por el subjetivismo al tratar acerca de los ca-

33 Alain BOYER y Maurice-Ruben HAYOUN, L'Historiographie Juive. París. Presses Universitaires de France, col. "Que sais-je?», 2001, p. 13

34 Abraham Ben David, Sefer Ha-Kabbalah Libro de la Tradición). Traducción por Jaime Bages, p. 15. 
raítas, cuando puntualiza sobre las persecuciones padecidas por los judios, o cuando intenta demostrar la falsedad de las fuentes cristianas (capítulo segundo), lo que le lleva a alterar de forma consciente la fecha de la crucifixión de Jesucristo, que retrasa hasta comienzos del siglo ॥ d.C. para, de este modo, rebatir la relación de causa-efecto de la muerte de Cristo y la destrucción del segundo Templo de Jerusalén, argumento éste muy utilizado por la literatura apologética cristiana desde los tiempos de San Justino, apologeta y mártir ( $\left.c^{a} 100-c^{a} 165\right)$; según ben David, Cristo habría sido crucificado después de la destrucción del Templo de Jerusalén:

«Los historiadores de Israel dicen que Yehosúa Ben Perajyah era maestro de Jesús el Nazareno, si esto es cierto vivió en el tiempo del rey Yaneo. Sin embargo, los historiadores de otros pueblos dicen que nació en la época de Herodes y que fue crucificado en tiempos de Arquelao, su hijo. La discrepancia consiste en la gran diferencia de más de 110 años que hay entre ellos. Los historiadores gentiles anotan sus hechos de varias formas: dicen que nació en el año 312 de la era seléucida y que fue crucificado treinta y tres años después, y que nació en el año 38 del rey Augusto - rey romano del tiempo de Herodes - y dicen que fue crucificado en el tiempo de Arquelao, su hijo. Ellos argumentan de este modo con objeto de afirmar que el Templo y el reino de Israel permanecieron poco tiempo después de la crucifixión. Pero nosotros tenemos una tradición verdadera de la Misnah y del Talmud que no cambian nada, pues Yehosúa ben Perajyah huyó a Egipto en tiempos de Alejandro, que era Yaneo, y con él huyó Jesús el Nazareno. En nuestras manos está la tradición auténtica: nació en el cuarto año del rey Alejandro, año 263 de la construcción del segundo Templo y año 51 del reinado de los hijos del hasmoneo. Fue hecho prisionero cuando tenía treinta y seis, en el tercer año del reinado de Aristóbulos, hijo de Yaneo" ${ }^{35}$.

Es éste un manejo histórico similar en cuanto a sus objetivos al que se urdió en la segunda mitad del siglo xv por parte de algunos autores hispano-hebreos en relación a la fecha de la llegada de los judíos a la Península Ibérica, que retrotraían al siglo vi a.C., a los tiempos del rey babilonio Nabucodonosor, pues de este modo los judíos hispanos quedarían libres de la acusación de deicidio, al no ser descendientes de los que habían provocado la muerte de Cristo en la cruz. Pero el hecho de que Abraham ben David redactara su obra con un propósito firme y determinado - la desacreditación del caraísmo-, que proyectara su visión particular sobre los acontecimientos narrados y que en ocasiones llegara, incluso, al falseamiento de datos, no llama tampoco excesivamente la atención en un momento en el que los historiadores árabes y cristianos expresaban también

35 Abraham IBN Daud, Libro de la Tradición. pp. 55-56. 
de forma abierta sus filias y fobias, lo que con frecuencia obedecía a que la obra histórica se redactaba al servicio de intereses políticos particulares.

No es infrecuente, por otra parte, la inclusión en el relato de algunas leyendas que en su tiempo eran tenidas como hechos históricos auténticos, aunque una crítica más depurada ha permitido más tarde demostrar su falta de veracidad. Asimismo algunos relatos parecen incluidos de forma algo forzada, presentando una manifiesta falta de conexión con la trama principal; es éste, por ejemplo, el caso del pasaje relativo a Rómulo y Remo y a Julio César, que se incluye en el capítulo cuarto dedicado al orden de los amoraítas.

No obstante, y pese a sus deficiencias, el Sefer ha-Qabbalah es una obra de enorme trascendencia en la historiografía y en la cultura hebrea en general, influyendo de forma considerable en los cronistas judios posteriores, en particular en los de origen hispano. Buena prueba de la difusión que esta obra tuvo a lo largo de las Edades Media y Moderna son los numerosos manuscritos que se han conservado de ella, así como las sucesivas ediciones impresas de que fue objeto, desde la primera de Mantua de 1514. En cualquier caso, más que por tratarse de una fuente original o por la fiabilidad absoluta de las noticias que transmite, el mayor valor de esta crónica consiste en que es expresión patente de una forma de concebir la historia que era compartida por buena parte de los intelectuales judíos de época medieval.

Un análisis detenido del Sefer ha-Qabbalah permite comprobar que en esta obra se funden las dos tradiciones intelectuales propias de los judíos andalusíes: la hebrea y la árabe. Así, si por lo que se refiere al objetivo que guía su composición -el combate contra el caraísmo- esta crónica puede considerarse como propiamente hebrea, desde un punto de vista formal no cabe duda de que, en gran medida, utiliza las técnicas y los recursos de la historiografía árabe. En este sentido, el propio tema de la cadena de transmisión de la tradición, aunque tenía algunos precedentes en la literatura hebrea - por ejemplo, en el tratado Pirqé Abot de la Mishnah-, está fuera de toda duda que fue en la historiografía árabe donde mayor desarrollo alcanzó, de tal forma que llegó a constituir una especie de subgénero dentro de ella. $Y$ otro tanto cabe decir respecto a la periodización por generaciones, que es un sistema de división cronológica utilizado tanto en la literatura hebrea -en el Pirqé Abot- como en la árabe, donde es denominado tabaqa (= nivel, capa). Del mismo modo, la estrecha vinculación de historiografía con biografía y genealogía es otro rasgo común a las tradiciones historiográficas hebrea y árabe, que se hace también patente en el Sefer haQabbalah en el esfuerzo de Abraham ben David por hacer constar las fechas más destacadas en la vida de los principales maestros mencionados a 
lo largo del texto, así como en el trazado de alguna biografía, como la de Samuel ibn Nagrella, de quien afirma ser el primer eslabón en Sefarad de la cadena de transmisión de la tradición. Por último, parecen también influencia de la historiografía árabe la estructura del Sefer ha-Qabbalah en capítulos y, de forma muy particular, la técnica consistente en la utilización de cartas y documentos como fuente histórica.

Pero la influencia de la historiografía árabe en la obra de Abraham ben David va más allá de estas cuestiones de carácter técnico, y afecta a algo mucho más importante como es la propia concepción de la historia. En este sentido, no es descartable que la elección por parte de ben David del género cronístico para su crítica contra el caraísmo obedezca al desarrollo y al gran prestigio que la literatura historiográfica conocía en el siglo xII en al-Andalus ${ }^{36}$. Del mismo modo, el Sefer ha-Qabbalah participa también del objetivo ejemplarizador que los relatos históricos tienen en el mundo árabe medieval, lo que tiene su más clara manifestación en el epílogo de esta obra cuando, frente a la expansión y al vigor de los comunidades rabanitas, en las que la cadena de la tradición se mantuvo siempre unida, ben David opone la disgregación que padecen los caraítas, reducidos además a unas pequeñas comunidades en el Magreb, en Egipto y en Palestina:

"Hubo, pues, diez generaciones desde los profetas Hagay, Zacarías y Malaquías hasta Rabbán Yojanán ben Zakkay, cinco de los tannaítas y siete de los amoraítas. Esto suma un total de veinte y dos generaciones hasta el final de los amoraítas. De rabinos saboraitas hubo ocho generaciones, cinco de gaones y tres de rabinos: la de R. Nissim, R. Jananel y R. Semuel haNagid, la generación de cinco rabinos llamados todos Yisjak, la de R. Yosef ha-Leví, de bendita memoria. El número de generaciones en conjunto es de treinta y ocho desde Hagay, Zacarías y Malaquías hasta R. Yisjaq, de bendita memoria, y el maestro R. Baruk bar Yisjaq.

Todos ellos son fieles testigos que hablan por boca de fieles testigos. La santa cadena de la tradición no se rompió.

Esto no lo encontrarás entre los herejes. Anán, el impío, y Saúl, su hijo, ¡que el nombre de los impios se corrompa!, fueron discípulos de Rab Yehuday y se separaron de él y su tradición no por una objeción en algún tema sino por la envidia que sentían. Ellos no pueden decir: 'Asi fue transmitida a nosotros a través de fulano y a fulano de los profetas', sino que ellos inventan de sus propios corazones.

Además, ellos son una minoría de ociosos. Tú encuentras comunidades de Israel que se extienden desde Salé, al final del Magreb, a Tahert, al principio del Magreb, y a Ifriquiya, Egipto, Tierra Santa, Arabia, Iraq, Elam,

36 ABRAHAM IBN DAUD, Libro de la Tradición. Introducción, traducción y notas por Lola Ferré, p. 26. 
Persia, Dedan, Girgas, llamada Gurgán, Tabaristán, Daylam hasta el río Volga. Allí está el pueblo de los jázaros que se convirtieron y su rey envió un libro a R. Jasday ha-Nasí bar Yisjaq ben Saprut, informándolo de que él y su pueblo se esforzaban por seguir la sabiduria del rabinato ${ }^{37}$.

Dentro del plan general de la obra, Abraham ben David dedica una particular atención a los aspectos propiamente relacionados con la historia judía; cuando se tratan cuestiones relativas a la historia universal es siempre en relación directa con asuntos que atañen al pueblo hebreo. Teniendo en cuenta que el objetivo básico que en ella se persigue es la desacreditación del caraísmo, no es extraño que el autor se interese de forma muy especial por las sectas judías, centrando su atención, además de en el propio caraísmo, en los saduceos y en los samaritanos. Con el fin de reforzar su tesis acerca de la existencia de una corriente única y auténtica dentro del judaísmo "oficial» - lo que un análisis detenido del Sefer haQabbalah desmiente de forma rotunda, al verificarse en diversos pasajes de esta obra enfrentamientos entre diferentes corrientes del judaísmo "oficial»-, Abraham ben David sostiene la idea de que todas las sectas forman parte, en realidad, de una misma escisión, que se manifestaría en diferentes momentos históricos. En este sentido, insinúa una más que improbable relación entre caraítas y samaritanos, así como un origen saduceo del cisma caraíta, lo que sí entra dentro de lo posible ${ }^{38}$.

Otra cuestión interesante es la que se refiere al esquema de desarrollo histórico establecido por ben David en su crónica, y que, en sus líneas generales, se corresponde con el esquema de sucesión de los cuatro grandes imperios que, según la visión profética de Daniel, culminaría con la venida del Mesías. En el capítulo VII del libro de Daniel se describe la visión que el profeta tuvo de cuatro bestias y del juicio que Dios haría sobre ellas, y que han sido identificadas con cuatro de los grandes imperios de la Antigüedad: el león con Babilonia, el oso con Media, el leopardo con Persia y la bestia sin nombre con Alejandro Magno. Este esquema tuvo éxito, y fue aceptado en adelante como modelo para la interpretación de la evolución histórica de la humanidad, si bien con sucesivas y necesarias adaptaciones; de este modo, para San Jerónimo la historia de la humanidad estaría dividida en cuatro grandes edades, que se corresponderían con la historia de los cuatro grandes imperios de la Antigüedad: el imperio asirio-babilónico, el imperio medo-persa, el imperio greco-macedónico y el imperio romano. Más tarde, el surgimiento del Islam obligó a los judíos de época medieval a adaptar

37 Abraham IBN Daud, Libro de la Tradición, pp. 102-103.

38 AbRaham IBN Daud, Libro de la Tradición. Introducción, traducción y notas por Lola Ferré, p. 28. 
nuevamente el tradicional esquema de las cuatro edades, por cuanto el último reino de la visión de Daniel ya no podía corresponderse con Roma, sino que tenía que ser el Islam; así, ben David establece la siguiente secuencia histórica: Persia (con Babilonia y Media), Grecia (con Roma), Persia-Roma (imperios persa-sasánida y bizantino) e Islam.

La valoración que ben David hace de los sucesivos imperios varía desde la más positiva referida a Persia y a Roma -el rey Ciro es denominado "el ungido", y el sentimiento dominante con respecto a Roma es el de admiración-, a la más negativa que es la de Grecia, muy probablemente como consecuencia del abierto rechazo que producía en el mundo hebreo el proceso de helenización al que se vieron sometidos los judíos durante la dominación griega.

Es curiosa también la toma de postura de ben David en relación con algunos de los acontecimientos más señalados de la historia del pueblo judío. Así, en tanto que en el capítulo segundo muestra su admiración por la revuelta de los Macabeo contra los seléucidas (s. II a.C.), señalada como prototipo del amor a la independencia, en el capítulo tercero valora negativamente la revuelta de Bar Kokbá frente a Roma (132-135 d.C.), por considerarla una provocación inútil que acarrearía grandes desgracias para el pueblo judio; es muy posible que en esta toma de postura influyera el desprecio que ben David sentía hacia Bar Kokbá por haberse autoidentificado con el Mesías.

Otro aspecto fácilmente detectable a lo largo de toda la obra es una manifiesta sobrevaloración del papel histórico que desarrolló el pueblo judío. Es suficientemente elocuente a este respecto la insinuación que se hace en el capítulo cuarto a que Roma se alzó contra Grecia tomando como ejemplo la revuelta de los Macabeo:

"Cuando vencieron los hijos del hasmoneo a Antíoco y su reino, también los romanos se reunieron, defendieron sus vidas y fortaleciéndose se libraron del yugo de los griegos, reinaron sobre ellos y les pusieron un impuesto" ${ }^{39}$.

Pero más allá de una simple admiración por el pasado histórico del pueblo hebreo, es posible que esta actitud del cronista responda más bien a un plan minuciosamente concebido. En efecto, la redacción del Sefer ha-Qabbalah coincide en el tiempo con uno de los momentos más críticos en la historia del pueblo judío en la Península lbérica; unos años antes los almohades habían invadido al-Andalus y habian provocado la ruina de las en otro tiempo esplendorosas comunidades judías andalusíes y la emigración de

39 Abraham IBN Daud, Libro de la Tradición, p. 70. 
muchos de sus miembros hacia los reinos cristianos del norte. Quizás, para combatir el fuerte desánimo que debía gravitar sobre los espíritus de los judios andalusíes, ben David trataba de transmitir en su obra una firme esperanza en la redención mesiánica, así como ofrecer la imagen de una tradición fuerte y vigorosa y de un pueblo que en los momentos más difíciles de la Historia había dado muestras sobradas de fortaleza, de valor, de unidad y de espiritu de independencia.

Según la secuencia establecida por Abraham ben David, los cuatro reinos ya habian hecho su aparición en la historia, por lo que no parecía lejana la fecha de la llegada del Mesías. En cualquier caso, los tiempos mesiánicos irían precedidos del triunfo y derrota del Islam. De este modo, es muy probable que, además del firme combate del caraísmo, en el ánimo de Abraham ben David pesara también el deseo de transmitir un mensaje de importancia trascendental para el pueblo judío como era la próxima llegada del reino mesiánico. Pese a que no es posible valorar hasta qué punto el mensaje de ben David acerca de la proximidad del reino mesiánico fue captado por sus contemporáneos hebreos, de lo que no cabe ninguna duda es de la importante repercusión que el Sefer ha-Qabbalah tuvo en las siguientes generaciones del judaísmo hispano, hasta el punto de que tres siglos después de que fuera escrita fue proseguida su redacción por Abraham ben Salomón de Torrutiel, lo que es una señal inequívoca de que no sólo no había caído en el olvido sino que, muy al contrario, se consideraba conveniente y útil su continuación ${ }^{40}$.

Del éxito alcanzado por el Sefer ha-Qabbalah de Abraham ben David son buena muestra las sucesivas ediciones que de esta obra se hicieron a lo largo de los siglos XVI (Mantua, 1514; Venecia, 1545; Basilea, 1580) y XVIII-XIX (Amsterdam, 1711; Korez, 1785; Polnoh; y Cracovia, 1820), además de su utilización habitual en la mayor parte de las obras de cronología hebreas a lo largo de las Edades Media y Moderna.

\subsection{El capítulo 50 del Qissur zeker Saddiq (Compendio de la memoria del justo), de Rabi Yosef ben Saddiq de Arévalo}

Rabí Yosef ben Saddiq de Arévalo vivió en esta localidad abulense, donde redactó su obra de derecho judío titulada Qissur zeker Saddiq, que concluyó hacia el año 1487. Como explica el propio autor en la introducción, la

40 Abraham IBN DAUD, Libro de la Tradición. Introducción, traducción y notas por Lola Ferré, p. 33. 
finalidad de esta obra consiste en explicar de forma breve el significado de las diversas leyes y ceremonias de la religión judía; a modo de complemento, en el capítulo 50 Rabí Yosef hace una cronología de Israel, desde la creación del mundo hasta su tiempo, que es lo que en este momento nos interesa por su contenido historiográfico.

En este capítulo, además del recuerdo de las generaciones del antiguo Israel hasta la destrucción del segundo Templo, se hace también referencia a la sucesión de los órdenes de maestros del judaísmo - Tannaim, Amoraim, Saboraim y Gaonim - para, seguidamente, tratar sobre los rabinos más destacados de Ashkenaz (Alemania), de Sarfat (Francia), de Babilonia y de toda la tierra de Ismael (es decir, de los territorios bajo dominio islámico) y de Sefarad (España); de cada uno de ellos se indica su lugar de residencia, sus escritos y otros hechos especialmente relevantes de su tiempo. Concluye con el recuerdo de los reyes de España y Portugal, y con el relato de la destrucción de Constantinopla y el Nigroponte.

Por lo tanto, el capítulo 50 del Qissur zeker Saddiq consiste en una crónica breve, ordenada en los seis períodos milenarios de la era judaica; dentro de cada uno de estos períodos, Rabí Yosef establece las mismas subdivisiones temporales o "generaciones" que las fijadas por Abraham ben David en su Sefer ha-Qabbalah. Porque el objetivo básico de Rabí Yosef es también, como el de ben David, recordar la cadena de transmisión de la Ley; no obstante, no hace ya una crítica acerada contra el caraísmo, por cuanto en el momento en que redactó su obra esta herejía había ya prácticamente desaparecido de España.

En general, esta crónica se reduce a un mero recordatorio de nombres y fechas, por lo que su interés histórico es bastante limitado. Sólo al final el autor se olvida un tanto del esquema general de la obra -la cadena de transmisión de la tradición-, de forma que, junto con noticias relativas a los sabios judíos hispanos, Rabí Yosef relata algunos hechos históricos referidos a los reyes de España y Portugal desde comienzos del siglo $\mathrm{xl}$, centrando su atención, de forma primordial, en sus relaciones familiares, en las operaciones bélicas de las que fueron protagonistas y en otros diversos aspectos relacionados con la historia política de su reinado. Una de las figuras a las que dedica mayor atención es al rey Alfonso $X$ el Sabio, poniendo de relieve su importante contribución cultural:

«El rey don Alonso el Sabio, hijo del mencionado rey don Fernando, reinó después de él setenta años, en el 5052 de la creación, que es el 1290 de César y el 1252 para el cómputo de los cristianos. Casó con doña Violante, hija del eximio sabio rey don Jaime de Aragón, que recibió la sabiduría de 
Ha-RaMba"N ${ }^{41}$, su recuerdo para bendición; tuvo de ella dos hijos: don Fernando de la Cerda y don Alonso de la Cerda. Conquistó el reino de Murcia y en el año cuarto de su reinado ordenó al sabio Gudsal ben Monse al-Kohen, del concejo de la ciudad de Toledo, traducir de la lengua árabe a la lengua vulgar el honorable libro que había compuesto el sabio Albuhatani Abd-al-Rahman ben Umar Asufi, que habla de asuntos de las estrellas y el zodiaco y sus figuras según los dibujos del cielo. También se copiaron las tablas que compuso este rey acerca de astronomía y mis ojos vieron este libro honorable y estaba escrito todo él de oro puro y digo que quien no vio este libro no vio un magnífico y bello objeto (nunca). Este rey, con su mucha sabiduria -era el más grande sabio en toda ciencia-, ordenó y estableció preceptos y leyes en sus asuntos religiosos para juzgar a todos los goyyim ${ }^{42}$ de su reino y las llamó Las Siete Partidas, porque en conjunto son siete. Ordenó guardar y cumplir todos estos preceptos y leyes y, según su contenido juzgasen todos los jueces. Desde que aparecieron estos libros y sus preceptos y sus leyes asi se habría de juzgar en todo el reino. Establecieron todos los sabios y reyes y príncipes y todo el pueblo que fueron después de él continuar con ellos hasta hoy. En su tiempo existió el sabio cabalista R. Yaaqob Chicatilla, enterrado en Segovia y su maestro el sabio Abar de Prayes. Falleció Ha-RaMba"N, su recuerdo para bendición, de Gerona, en Jerusalén el año 5002 (1242). Murió R. Yonah de Gerona en Toledo, discípulo de Ha-RaMba"N, su recuerdo para bendición, y R. Meir Ha.Kohen de Narbona, que vino de Barcelona, en el año 5024 (1264). R. Abraham bar Yoel ha-Ezri, llamado Abi ha-Ezri de Maenza en el 5024 (1264). R. Selomoh bar Eli de Soria, discipulo de R. Yonah, escribio Novellae acerca del Talmud según la tradición recibida, en el 5024 (1264). Falleció el piadoso santo Rabbi Yehiel ben Aser, padre de Ha-ROS ${ }^{43}$, su recuerdo para bendición, durante la fiesta de Sukkot, y atestiguó sobre él en su testamento R. Yehudah ben Aser, biznieto de Ha-ROS, su recuerdo sea para bendición, que se sonrió en su féretro a la vista de toda la comunidad judia y que fue a su casa y al Bet midras ${ }^{44}$ después de su fallecimiento el año 5024 (1264). R. Yishaq bar Selomoh ben Sahulah, el gran poeta, compuso Mesal ha-qadmoni en el 5028 (1268). Falleció R. Yishaq, el narigudo, de Corbeil, yerno de R. Yehiel de Paris, gran piadoso, de los grandes de Atra, compuso el Sefer ha-miswot ha-qatan, llamado Amude ha-golah en el 5030 (1270)" ${ }^{45}$.

Como resulta evidente a través de la lectura del pasaje anterior, en los relatos sobre los distintos monarcas se hace especial hincapié en todo tipo de noticias relativas a la comunidad hebrea; de este modo, al tratar sobre el rey Enrique III se hace alusión a los asaltos sufridos en el año 1391 por buen número de juderías hispanas:

41 Se trata de Moseh ben Nahman, más conocido como Nahmánides (1194-c $\mathrm{c}^{\mathrm{a}} 1270$ )

42 El término goyyim se emplea en la Biblia para referirse a los pueblos paganos. Más tarde sirvió a los autores hebreos para designar a cualquier pueblo no judio.

43 Se trata de Aser ben Yehiel (1250-1327/8), famoso talmudista de origen alemán que en 1305 fue nombrado rabino de la comunidad hebrea toledana.

44 Se trata de la escuela rabínica, generalmente aneja a la sinagoga.

45 Dos crónicas hispanohebreas del siglo xv, pp. 51-54. 
«El rey don Juan, hijo del rey don Enrique, reinó veintitrés años. Montaba a caballo este rey en Alcalá (de Henares) y corría con él y cayó de él y fue pisoteado, sus patas sobre su cabeza, le hirió y le hundió la sien, el año 5151 (1391). En el 5151 (1391) este rey ordenó anular y suprimir el cómputo de César ${ }^{46}$ por el que contaban todos los goyyim y comenzaron a contar según la era de Jesús el cristiano. Entonces allí se levantaron contra los judíos los enemigos y actuaron con ellos según su voluntad, a golpe de espada y destrucción apresando a sus mujeres e hijos y niños pequeños y los llevaron para vender como siervos y siervas y las hijas las llevaron venecianos por mar y las convirtieron en propiedad pública. Hicieron cambiar su religión por la del dios extranjero del país a más de doscientos mil judíos por orden del rey, que era joven, el año 5151 (1391) y le dieron la señal (mnemotécnica) de El Qana. Obligó el arcediano ${ }^{47}$ (a los judíos) a convertirse en Sevilla, Valencia, Lérida, Barcelona y Mallorca el año 5151 (1391), y la señal es El Qana» ${ }^{48 .}$

Pese a la indudable deuda que el capítulo 50 del Qissur zeker Saddiq tiene con el Sefer ha-Qabbalah de Abraham ben David, hay que destacar el esfuerzo de Rabí Yosef por completar las informaciones facilitadas en la obra que le sirvió de modelo, lo que es especialmente significativo en lo que se refiere a la época del Rabinato. Así, cita a numerosos sabios judíos, tanto españoles como de otros territorios, a los que no había hecho referencia ben David por centrarse en los maestros depositarios de la tradición; entre sus fuentes de información habría que incluir también, muy probablemente, algunas crónicas hispano-cristianas.

Por otra parte, la crónica redactada por Rabí Yosef presenta ya una combinación de lo que podría denominarse el estilo tradicional de la cronística hebrea con el estilo narrativo de las crónicas históricas propiamente dichas ${ }^{49}$. De este modo, más allá del objetivo principal consistente en demostrar la sucesión de la cadena de transmisión de la tradición judía, y en destacar a quienes fueron sus principales protagonistas, el autor se interesa también por cuestiones diversas relativas a la comunidad hebrea, en particular por aquellos acontecimientos históricos que tuvieron una especial incidencia sobre ella, como las persecuciones; incluso, en ocasiones desciende a detalles que resultan de indudable interés, como cuando hace referencias de carácter meteorológico o acerca de la producción agrícola, lo que es ya indicativo de una importante evolución en la concepción historiográfica:

46 Se refiere a la llamada era hispánica (38 años antes de Cristo).

47 Se refiere a Ferrán Martínez, arcediano de Écija, promotor del levantamiento antijudio en Sevilla en 1391

48 Dos crónicas hispanohebreas del siglo xv, pp. 60-61.

49 Dos crónicas hispanohebreas del siglo xv. Introducción de Ron Barkai, p. 19 
«En el año (5)246, que fue el año (1)485 para los cristianos, el $18 \mathrm{del}$ mes de Hesvan, en este día, la lluvia cayó sobre la tierra durante sesenta días y sesenta noches y, en verdad, que desde el diluvio hasta hoy no hay recuerdo ni en los ancianos ni en los jóvenes que habia entonces (en esta generación) de que vieran ni escucharan tan gran prodigio como éste. $\mathrm{Ni}$ hemos escuchado ni hemos visto escasez de lluvias como aquellas en el año (5)247, durante nueve meses: enero, febrero, marzo, abril, mayo, junio, julio, excepto un poco, no cayeron lluvias sobre (la tierra). En el año (5)247 (1487) por parte de la providencia divina la medida de trigo costaba 90 monedas de oro, y la medida de cebada 45 . En el año (5)247 (1487) tomó nuestro señor el rey Torrox y Vélez Málaga y conquistó la ciudad de Málaga, la soberbia ciudad que estaba asentada a la orilla del mar de Occidente, en sábado, 29 del mes de 'Ab, que fue este día el 18 de agosto del año (1488) de los cristianos y fue sitiada cuatro meses y fueron cautivados todos los habitantes de la ciudad, unas doce mil almas de los ismaelitas y entre ellos unos cuatrocientos de Israel; y las comunidades judias rescataron sus almas por una gran cantidad (de dinero) $" 50$.

Diversos autores han puesto de manifiesto el marcado paralelismo existente entre el Qissur zeker Saddiq y el Sefer Yuhasín de Abraham Zacut, obra esta última algo posterior en el tiempo, y que es fácilmente observable tanto en el estilo literario como en las narraciones incluidas en el texto. Algunos de estos autores - Adolf Neubauer, Isidore Loeb- son de la opinión de que este paralelismo obedece a que ambas obras se basaron en las mismas fuentes; parece no obstante más verosímil, como sostiene A. Harkavy, que la semejanza responda a que Zacut utilizó la obra de Rabí Yosef como fuente fundamental para la redacción de su Sefer Yuhasín ${ }^{51}$.

\subsection{El Sefer Yuhasín (Libro de los Linajes) de Abraham Zacut}

Abraham ben Samuel Zacut nació en Salamanca, en torno al año 1450, en el seno de una familia oriunda de Francia, que se trasladó a España a comienzos del siglo XIV.

Fue discípulo de los gaones Yishaq ben Ya'aqob Campantón (1360?1463) y Yishaq Aboab el Menor (1433-1494), por lo que su formación literaria fue la propia de un rabino de la época, con grandes conocimientos talmúdicos, jurídicos y cabalísticos. Aunque muy probablemente fue su obra de cronología, denominada Sefer Yuhasín (Libro de los Linajes), la que le dio más renombre entre sus correligionarios, Abraham Zacut alcanzó también

50 Dos crónicas hispanohebreas del siglo xv, pp. 64-65

51 Dos crónicas hispanohebreas del siglo XV. Introducción de Ron Barkai, p. 18. 
justa fama como matemático, astrólogo y astrónomo, ciencia ésta a la que dedicó algunos de sus tratados. La elevada reputación que consiguió en estas disciplinas le permitió ejercer el magisterio en las universidades de Salamanca y de Zaragoza.

En 1492, y como consecuencia de la promulgación del decreto de expulsión, se estableció en Lisboa, donde fue agregado a la corte del rey Juan II (1481-1495) como astrónomo y cronista. Mantuvo esta privilegiada posición con el rey Manuel I (1495-1521), quien le consultó, en su faceta de astrólogo, acerca de la oportunidad de la expedición que proyectaba Vasco de Gama (1469-1524) para llegar a la India rodeando el continente africano, y para la que había diseñado un astrolabio reformado.

Al ser expulsados los judíos de Portugal, Abraham Zacut se trasladó primero al Magreb, y más tarde a Italia y Turquía, falleciendo en Damasco en torno al año 1522. Las penalidades sufridas en el exilio, de las que da cuenta en la introducción del Sefer Yuhasín - así, señala que su salud y su capacidad intelectual se resintieron como consecuencia de las mismas-, motiva una actitud de gran dureza para con todos los perseguidores del pueblo de Israel.

En definitiva, se trata de una figura muy representativa del pensamiento judío medieval, y buen exponente de la cultura literaria y científica de los judíos españoles en los tiempos de la expulsión.

En la línea de las obras más relevantes de la cronología hebrea medieval, el Sefer Yuhasín ofrece un compendio de la cadena de transmisión de la tradición judia, haciendo especial hincapié en la historia de los sabios hebreos, desde los tannaítas hasta su tiempo, lo que el autor considera de gran provecho para el fortalecimiento de la Ley oral y de la tradición; como otros autores hispano-hebreos, Abraham Zacut dedica una atención muy particular a los maestros de la Ley que se sucedieron en España. Asimismo se incluye en esta obra una síntesis de historia universal judía desde la creación del mundo.

Para las primeras secciones del Sefer Yuhasín, Zacut utilizó como fuente de información, principalmente, el Sefer ha-Qabbalah de Abraham ben David, del que transcribió textualmente largos pasajes. Para las secciones posteriores, y como ya se ha indicado en otro lugar, se observa un notable paralelismo entre el Sefer Yuhasin y el Qissur zeker Saddiq de Rabí Yosef ben Saddiq de Arévalo, lo que ha llevado a algunos autores -A. Harkavy - a afirmar que Zacut se basó en el capítulo 50 de la obra de Rabí Yosef, en tanto que otros - Adolf Neubauer, Isidore Loeb-, teniendo en cuenta las diferencias existentes entre ambos textos, son de la opinión de que ambos historiadores se basaron en una misma crónica, 
desconocida y más antigua. Asimismo utilizó también Zacut otros escritos de carácter no propiamente histórico, no sólo de autores judíos, sino también de cristianos y musulmanes.

Pese a que algunos especialistas achacan a Zacut poco sentido crítico en el uso de las fuentes de información, lo que le llevaría a incurrir en frecuentes errores históricos, los principales críticos actuales coinciden en señalar su gran esmero en el tratamiento de los detalles y su alta erudición, que hacen del Sefer Yuhasín una fuente interesante para el conocimiento histórico, en particular para los períodos postalmúdico y rabínico, siempre que se haga uso de esta obra con las debidas precauciones.

\subsection{El Sefer ha-Qabbalah de Abraham ben Salomón de Torrutiel}

Nació el autor de esta obra en la localidad valenciana de Utiel, en el año 1482; su padre, Rabí Salomón de Torrutiel, era un reputado talmudista, discípulo del famoso rabino castellano Yishaq ben Ya'aqob Campantón (1360?-1463). Cuando contaba con diez años de edad, y como consecuencia de la promulgación del decreto de expulsión general de 1492, partió con su familia hacia el exilio, estableciéndose en Fez, ciudad en la que concluyó su crónica en el año 1510 (5270 de la creación), y en cuya comunidad hebrea tuvo una destacada participación.

\subsubsection{Objeto y plan general de la obra}

Abraham ben Salomón de Torrutiel denominó a su crónica Sefer haQabbalah (Libro de la Tradición), del mismo modo que la crónica de Abraham ben David en la que se inspiró y de la que pretende ser continuación. En un breve prólogo explica el objeto y el plan general de su obra, en los siguientes términos:

«Dijo Abraham, hijo del sabio, perfecto y piadoso Rab Selomoh de Torrutiel, según to que Rabbi Abraham bar Daud, su recuerdo sea para bendición, compuso en el libro llamado Sefer ha-Qabbalah, ya mencionado, en el año 4921 (1161) de la creación del mundo; en él expuso las generaciones de los sabios que existieron desde la época de los hombres de la Gran Asamblea hasta su propia generación, que fue la de Rab Yosef ha-Levi ben Migas, discípulo de Rab Alfasi, maestro de Ha-RaMba»M. He creído conveniente completarlo desde el año que murió el maestro, de bendita memoria, que fue el año 4970 (1210), hasta este mismo año que es el 5270 (1510) de la creación, con el fin de dar a conocer a nuestras generaciones futuras que la tradición se ha continuado, desde el maestro al discípulo, desde el año 
que le fue entregada en el Sinaí, desde hoy y hasta este momento; y asi será hasta que venga el Maestro de Justicia (el Mesías) » 52 .

La obra la divide el autor en tres capítulos: en el primero incluye a los sabios que precedieron a Abraham ben David y a los que él no mencionó en su libro; en el segundo recuerda a los sabios que vivieron desde los tiempos de Abraham ben David hasta los de Rabí Yishaq ben Ya'aqob Campantón (muerto en Peñafiel en 1463); y en el tercero hace referencia a algunos de los reyes de la España cristiana medieval hasta los tiempos de Fernando el Católico, dedicando también su atención a la guerra de Granada, al destierro de los judios hispanos y portugueses, y a las circunstancias en que se desarrolló la vida de la comunidad sefardí de Fez tras su llegada desde España.

Los dos primeros capítulos consisten, por tanto, en una mera relación de los sabios judíos dignos de memoria por su aportación a la tradición hebrea. Al citar a cada uno de ellos, se hace especial hincapié en los rasgos más sobresalientes de su magisterio y en su producción literaria, así como en los más destacados acontecimientos de su vida, principalmente en las fechas de su nacimiento y muerte, en las que, no obstante, es fácil apreciar numerosos errores.

Desde el punto de vista histórico, el único capítulo auténticamente interesante es el tercero, ya que en él se contiene un relato de la historia hispana medieval entre comienzos del siglo xl y fines del siglo $x v$, desde el punto de vista de un autor judío, lo que aporta muy interesantes noticias acerca de la interpretación que de los acontecimientos históricos y de sus principales protagonistas hacia la comunidad hebrea. La narración se hace particularmente pormenorizada cuando se centra en hechos que el autor vivió personalmente y de los que fue testigo directo.

Con relación a la obra de Abraham ben David en la que se inspiró, el Sefer ha-Qabbalah de Abraham ben Salomón de Torrutiel presenta una notable disparidad, que tiene mucho que ver con los momentos históricos, muy diferentes, en los que ambas obras fueron redactadas. Así, en la crónica de Torrutiel desaparecen las referencias al espíritu de justicia de los monarcas hispano-cristianos tan frecuentes en la crónica de ben David, de forma que son rarísimas las alabanzas que se pronuncian en favor de alguno de ellos. Frente a la concepción del monarca ecuánime y justo que tenían los judíos del siglo XII, pues veían en él su principal

52 Dos crónicas hispanohebreas del siglo XV. Traducción y notas por Yolanda Moreno Koch, p. 69. 
valedor ante los enemigos internos y externos a la comunidad, no cabe ninguna duda de que la actitud de Torrutiel está en relación directa con un sentimiento de hostilidad hacia los monarcas hispano-cristianos como consecuencia de la promulgación del decreto de expulsión; como los otros cronistas hispano-judíos coetáneos, Abraham ben Salomón de Torrutiel pertenece a una generación de historiadores que presenta, en ocasiones de forma excesivamente apasionada, las desgracias padecidas por el pueblo hebreo, y que responde de forma muy crítica a los argumentos empleados por los escritores hispano-cristianos de su época. De este modo, no son raras las maldiciones lanzadas contra los monarcas cuya política había sido más desfavorable para la comunidad hebrea; sirvan de ejemplo las diatribas que lanza contra los Reyes Católicos, a los que acusa de ser los causantes de la perdición de la comunidad hispano-hebrea, y con quienes se muestra particularmente violento:

"Y el rey (Fernando), con la maldad de Amalek de Sodoma, se hizo fuerte junto con su mujer, la aborrecible en el reino; prosperó y organizó un ejército (mayor) que el de todos los reyes que le precedieron. En el año undécimo de su reinado, el año 242 (1482) del cómputo menor, después de que fue conquistada Alhama por don Rodrigo, marqués de Calis, comenzaron los jueces del rey a investigar acerca de los conversos en lo tocante a religión y los encontraron que eran fieles a la religión del Dios de israel. Fueron todos condenados a la hoguera y su riqueza pasó al rey para restablecer lo que se dijo 'y arrojaré la tercera parte al fuego' 53 . En aquel mismo año el rey ordenó hacer separación entre los lugares de residencia de los judíos y los goyyim $" 54$.

El relato histórico del capítulo tercero se inicia en el reinado de Fernando I de Castilla y León (1037-1065); al tratar sobre cada monarca se interesa, principalmente, por las conquistas llevadas a cabo frente a los musulmanes, así como por los acontecimientos que afectaban directamente a la población hebrea, en particular cuando se trata de penalidades y persecuciones, que achaca, como es habitual entre los autores judios de época medieval, al abandono por parte de sus correligionarios de la tradición hebrea. La narración del exilio de 1492 alcanza las cotas máximas de patetismo de toda la obra, describiendo con gran realismo el dolor y la desesperanza que la publicación del decreto de expulsión produjo en todas las comunidades hispano-judías:

Ezequiel, $\mathrm{V}, 2$

54 Dos Crónicas hispanohebreas del siglo XV, p. 103 
"Se inflamó la ira de Adonay contra su pueblo y fueron expulsados de las ciudades de Castilla por el rey don Hernando y el consejo de su malvada mujer que era Isabel, la perversa, y por la opinión de sus consejeros; en el primer mes, que es el mes de Nisán, se trocó la alegría en aflicción y gemido. Salió el pregonero por todo el reino de Sefarad que estaba bajo su gobierno y un mensajero leyó con fuerza: 'A vosotros, judios, que habitáis en todo mi reino se os ordena que salgáis de mi país en el plazo de tres meses y toda persona que se oponga, todo el que desobedezca mi edicto, una sola cláusula, será ajusticiado'. En todo lugar en el que la palabra del rey y su mandato se dio a conocer, el dolor fue grande para los judíos, ayuno y lágrimas, gritos, cilicio y ceniza ponen sobre si ${ }^{55}$ para muchos de ellos, en el mismo día primero de Pesah en lugar de Aggadah hubo llanto amargo, ruina a cambio de las massot y hierbas amargas. Lloró el pueblo aquella noche y hubo una gran angustia. Desde Pesah hasta la fiesta de las Cabañuelas, salió todo el ejército de Adonay del país de Sefarad, el ejército a quienes tocó Elohim su corazón, abandonaron sus posesiones, dejaron su tierra y pusieron las miradas ávidas para buscar la palabra de Adonay y a David, su rey, por mar y tierra, de todo corazón y espíritu dispuesto. Algunos de ellos marcharon a la tierra del ciervo (Israel) o a la tierra de Amasia, a Grecia y a Turquía. La mayoría penetraron en el reino de Portugal, que estaba bajo el poder del rey don Juan, hijo del rey don Alonso; alli dejaron todas sus joyas, su plata y su oro, los hijos y las hijas" ${ }^{56}$.

Especialmente crítico se muestra con los que renunciaron a la fe de sus antepasados y aceptaron el bautismo, y de forma muy particular con los dirigentes de la comunidad quienes, en su opinión, debían haber dado ejemplo de perseverancia en la fe:

«La mayoria de los judios, sus grandes, sus señores y sus jueces permanecieron en sus casas y cambiaron su ley por la ley del Dios extranjero del país; abandonaron la fuente de agua viva y al Rey del mundo y sirvieron a otros dioses que no conocian ni tienen parte, que son madera y piedra ${ }^{57}$; no hacen mal, ni daño, ni benefician. Al frente de la multitud de los apóstatas estaba el rab don Abraham Seneor, rab de las comunidades de Sefarad ${ }^{58}$; él, sus hijos y todos los suyos, y como éstos, por miles, una gran cantidad, fueron borrados del Libro de los vivos, pues pecaron e hicieron pecar a muchos, ya que los ojos de muchos pendían sobre ellos, y por eso el pecado de muchos depende de ellos. No salieron de los grandes de Sefarad y de sus

\section{Ester, IV, 3.}

Dos crónicas hispanohebreas, pp. 104-105.

Deuteronomio, XXVIII, 36, y XXIX, 25.

Don Abraham Seneor fue Rab Mayor de los judíos de Castilla, cargo de nombramiento regio, y desempeñó importantes tareas financieras en la corte de los Reyes Católicos; en 1492, tras la promulgación del decreto de expulsión, fue bautizado por el cardenal Mendoza y apadrinado por los propios monarcas, lo que es un signo evidente de su relevancia en la vida cortesana de la Castilla de fines del siglo xv. 
dirigentes sino de unos pocos que pusieron sus miradas ávidas para morir mártires, se ofrecieron a si mismos, unos a la muerte, otros al castigo ${ }^{59}$.

Por el contrario, resalta la actitud de firmeza en la fe mantenida por algunos destacados personajes de la comunidad hebrea, entre los que menciona a Yishaq Abravanel ${ }^{60}$ y a Salomón Seneor, hermano de Abraham Seneor:

«El más grande de todos ellos, el gran hombre, el príncipe, el importante, el gran sabio rab don Yishaq Abravanel - sea su recuerdo para bendiciónque santificó el Nombre en público a la vista del rey y príncipes, él y el sabio don Selomoh Seneor, el viejo, hermano del rab mencionado. Todos los sabios de Sefarad, desde sus grandes hasta sus pequeños, y sus discípulos y todos los suyos ganaron e hicieron ganar a muchos y la ganancia de muchos depende de ellos» ${ }^{61}$.

Seguidamente narra con una gran carga de dramatismo la suerte que corrieron los judios que se dirigieron al Magreb, asi como la favorable acogida que les prestó el sultán de Fez:

"Y si tuviera que escribir en particular lo que les sucedió, el tiempo se acabaría y los temas no. No escribiré sino una parte de las aflicciones que sobrevinieron sobre los expulsados: parte de ellos entraron en la ciudad de Fez bajo el poder del gran rey, el justo más grande de todas las naciones del mundo, Muley Sek, que recibió a los judios en todo su reino y los benefició. Otros se reunieron en Salé, que estaba situada a orillas del mar de Occidente, y alli pasaron grandes amarguras por culpa de los incircuncisos Tomás y Julián, que atentaron contra las hijas de Israel; les odiaron, cometieron grandes abominaciones y ultrajes sin igual hasta el momento en que llegaron a la ciudad de Fez. Hubo otros que entraron en la ciudad de Arcila, que estaba bajo el poder de Nomrod, el perverso (quien les infligió) grandes castigos y encarnizadas crueldades; el impuro Kusan Ris 'ataim, capitán del rey de Portugal, encargado de Arcila, el llamado Conde de Barba por todo el mal

59 Dos crónicas hispanohebreas del siglo xv, pp. 105-106.

60 Yishaq ben Yehudah Abravanel (1437-1508) nació en Lisboa, donde su familia, de origen sevillano y con influencia en el mundo de los negocios, se habia refugiado tras las persecuciones de 1391. Ocupó puestos destacados en la corte portuguesa de Alfonso V, pero en el año 1483 se vio obligado a abandonar el país vecino, al ser acusado de estar implicado en una conjura nobiliaria contra el rey Juan II. Emigrado a Castilla, se estableció primero en Toledo y más tarde en Alcalá de Henares. Tras el decreto de expulsión partió hacia el exitio, estableciéndose en un primer momento en Nápoles y más tarde en Venecia, donde falleció en 1508. Además de su faceta de cortesano y financiero, Yishaq Abravanel destacó asimismo como filósofo y como comentarista bíblico, manifestando en todo momento una posición radicalmente antiracionalista (Ángel SÁENZ-BADILLOS y Judit TARgarona Borrás, Diccionario de autores judios (Sefarad. Siglos $x-x V$ ), pp. 146-148).

${ }^{61}$ Dos crónicas hispanohebreas del siglo XV, p. 106. 
que ocasionó a los judíos, que les arrojó en poder del rey de Alcazarquivir. Salieron contra ellos los árabes, los atacaron y cogieron todo lo que llevaban, dejándolos desnudos a hombres, mujeres y niños, una gran comunidad.

Hubo quienes entraron en la ciudad de Badis, bajo el poder de Muley Mansur, que actuó con gran bondad con Israel, hasta que marcharon a Fez con su riqueza y con todo lo que tenían. Hubo quienes entraron en Larache, pero cuando pasaban por Alcazarquivir salieron contra ellos los árabes y les infligieron grandes castigos; algunos de ellos murieron de sed, a otros los devoraron los leones. Acerca de ellos profetizó Isaias - sobre él la paz-: 'En la maleza, en la estepa pernoctáis, caravanas de Dedán; al encuentro del sediento traed agua ${ }^{62}$, etc; el resto de la evasión que sobrevivió fue a Fez - sea edificada la ciudad de Dios-. Se reunieron allí todos los grupos juntos, grandes y pequeños, sabios e inteligentes; entre ellos se encontraba mi padre - de bendita memoria - que contaba setenta años; después de infundir la Torah en Israel, falleció el día primero de Pesah del año primero de la salida de los judios de Sefarad" ${ }^{63}$.

La crónica concluye con la narración de los hechos acaecidos con motivo de la expulsión de los judíos de Portugal en 1496, en tiempos de Manuel I el Afortunado (1495-1521).

\subsubsection{El Sefer ha-Qabbalah como fuente para el conocimiento histórico}

Pese a que la crónica de Abraham ben Salomón de Torrutiel no pueda considerarse como de un gran valor histórico, la escasez de la producción historiográfica en la literatura hispano-hebrea, las interesantes noticias que facilita acerca de algunos de los principales sabios judíos $y$, principalmente, algunas narraciones de contenido histórico -en particular, la relativa a la salida de los judíos de los reinos hispanos-, le confieren indudable interés para el estudio del judaísmo hispano medieval.

Se ha discutido mucho acerca de las fuentes utilizadas por Torrutiel en la elaboración del Sefer ha-Qabbalah. De lo que no cabe ninguna duda es de que para la redacción de los dos primeros capítulos utilizó, además del Sefer ha-Qabbalah de Abraham ben David, el capitulo 50 del Qissur zeker Saddiq de Rabí Yosef ben Saddiq de Arévalo, de forma que puede apreciarse fácilmente un notable paralelismo en la exposición de los hechos y una forma de escribir muy parecida, pese a que no cite en ningún caso esta fuente de información; en cualquier caso, es más cuidado el estilo

62 Isaías, XXI, 13-14.

63 Dos crónicas hispanohebreas del siglo XV, pp. 107-108. 
de ben Saddiq que el de Abraham ben Salomón de Torrutiel. Es también probable que utilizara como fuente el Sefer Yuhasín de Abraham Zacut ${ }^{64}$.

Por último, nada seguro puede afirmarse sobre una probable utilización de algún otro tratado de contenido histórico hoy desaparecido.

\subsection{El Ma'amar 'al séder ha-dorot (Tratado sobre la sucesión de las generaciones) de Seadyah ibn Danan}

Seadyah ibn Danan nació en Granada, en torno a los años 14301440 , en el seno de una familia que, aunque quizás no de origen granadino, llevaba asentada en esta ciudad desde hacía varias generaciones, probablemente desde antes incluso de la persecución promovida contra los judíos por los almohades ${ }^{65}$; su abuelo, Rabí Moisés ben R. Maimón ibn Danan, fue un importante rabino y hakam en la comunidad granadina. Son muy escasos los datos biográficos que se han conservado acerca de Seadyah ibn Danan, quien debió morir en Orán, en el año 1493, tras haber dejado la Península Ibérica como consecuencia del decreto de expulsión.

Seadyah ibn Danan fue un autor polifacético del que, muy probablemente, no se ha conservado sino una pequeña parte de su producción. De la intensa actividad literaria que desarrolló merecen ser destacados, además de su Tratado sobre la sucesión de las generaciones, un diccionario hebreo bíblico-árabe, compuesto en árabe en el año 1468, y que va acompañado de una gramática de la lengua hebrea en la que el autor se revela como uno de los más sobresalientes teóricos de la prosodia hebrea; un breve tratado cabalístico filosófico sobre las letras, titulado Comentario de las letras y de sus formas, redactado en 1476; un opúsculo de influencia maimonidiana acerca de los géneros literarios de la Biblia; un comentario a la perícopa $\mathrm{He}$ aquí que mi siervo prosperará. Será exaltado y se elevará muy alto" (Isaías LII, 13), de contenido mesiánico; una Crónica de los reyes de Israel, escrita en árabe en 1480 y traducida más tarde al hebreo como Ma'amar 'al seder malke Israel, en la que se hace referencia al reinado de cincuenta y seis reyes de Judá y de Israel; un Responsum sobre los conversos forzados, redactado hacia 1480 en respuesta a la consulta

64 Dos crónicas hispanohebreas del siglo xv. Introducción de Ron Barkai, p. 19.

65 H. Edelman considera que la familia de Seadyah ibn Danan era originaria de la España cristiana, argumentando que en el Sefer Yuhasin se cita a un Rabí Maimón bar Seadyah entre los rabinos que huyeron de la España cristiana al norte de África con motivo de las persecuciones de 1391. 
formulada por la comunidad judía de Málaga en relación con los conversos; y otros diversos Responsa, comentarios y digresiones exegéticas, poemas y obras de menor relieve ${ }^{66}$.

Su obra denominada Ma'amar 'al séder ha-dorot (Tratado sobre la sucesión de las generaciones) se encuadra dentro del tradicional género literario judío de las «cadenas de transmisión de la tradición». La pretensión del autor es presentar, con intención probablemente didáctica, la relación de patriarcas, profetas y sabios judíos, desde Adán hasta Maimónides ( $\mathrm{m}$. 1204), a través de los que se habría transmitido la tradición de forma ininterrumpida, y de generación en generación.

La obra está escrita en hebreo, salvo una breve introducción en árabe. En ella, Seadyah afirma que al estudiar la halajá es necesario conocer el orden de los sabios y de sus generaciones, sus maestros y discípulos, y los que les precedieron y vinieron a continuación de ellos:

"Saadia -al que bendiga su Roca-- declara: He compuesto esta crónica sirviéndome de varias crónicas y escritos. La ordené adecuadamente y lo he logrado plenamente. Ciertamente que será muy útil para los estudiosos, puesto que, en el conocimiento de la halajá, necesitamos conocer el orden de los sabios y sus tiempos, sus maestros y (sus) discípulos, sus contemporáneos y los que les precedieron y siguieron " ${ }^{67}$.

Lo auténticamente singular del Ma'amar 'al séder ha-dorot con relación a otras obras de cronologia hispano-judías es su parte final, en la que se hace una loa encendida sobre Maimónides, lo que invita a suponer que el objetivo real de la obra fuera demostrar la legitimidad doctrinal de Maimónides, a quien se presenta como el último eslabón en la cadena de transmisión de la tradición:

"A la luz del Rab el gaón Rabbenu Moisés (Maimónides), hijo del Rab el juez Rabbenu Maimón, hijo del gran sabio Rabbenu Yosef, hijo del Rab Rabbenu Isaac, hijo del Rab el juez Rabbenu Obadia, hijo del Rab el juez Rabbenu Salomón, hijo del Rab Rabbenu Obadia, hijo del Rab el mártir Rabbenu Yosef, hijo del sabio Rabbenu Obadia, de bendita memoria, caminó todo Israel desde donde nace el sol hasta donde muere. Sus obras en todas las ciencias son de extraordinaria calidad. Si no fuera por su obra

66 Véase sobre este particular la introducción a la edición critica sobre el Tratado sobre la sucesión de las generaciones de la que son autores C. del Valle y G. STEmberger, Saadia lbn Danán. El orden de las generaciones. Seder ha-Dorot. Alcobendas. Aben Ezra Ediciones, 1997, pp. 17-43.

${ }_{67}$ C. del VAlle - G. Stemberger, Saadia lbn Danán. El orden de las generaciones. Seder ha-Dorot, p. 73 . 
sobre la Torá ${ }^{68}$ no entenderíamos el Talmud como es debido. También lo contrario es cierto. Tras él no surgió otro como él. Con justicia dijeron los sabios de las generaciones que vinieron tras él que fue el primero de los gaones por la excelencia y el último en el tiempo.

El gaón, el Rab, el Maestro - la memoria de nuestro señor sea bendita- nació en Córdoba un sábado, en tiempo de la oración vespertina, el catorce de Nisán del año 1446 de los seléucidas, año 4893 de la creación (1133 d.C.) ${ }^{69}$. Falleció (para gozar de) la vida del mundo futuro en Fostat la noche del lunes del 18 de Kislev del año 1517 de los seléucidas, 4965 de la creación (1205 d.C.) ${ }^{70}$, a los setenta y dos años aproximadamente. El féretro santo y puro fue sepultado en Israel, en la región de Tiberias, al lado de $\mathrm{R}$. Yojanán y de Rab Kahana I. ¡Feliz y bienaventurado él por siempre jamás, que todo él fue bondad y generosidad! ¡Feliz su porción y su suerte! ¡Ay de la generación de la que él desapareció! ¿Qué le sobrevendrá?

Mira, ahi, ante nosotros, está la luz de su sabiduria, la lámpara de sus libros y obras en su resplandor. Todo el que contempla la luz de los destellos de sus zafiros, de sus gemas, su corazón entenderá, sus ojos se iluminarán como si estuviera aprendiendo con la congregación de sus discípulos e hijos. Su recompensa está con él y su obra delante de él.

¡El Dios resplandeciente, creador de las tinieblas, formador de la luz, nos ilumine con la luz de su maravillosa enseñanza! Con ella conoceremos su Existencia y su Unidad. Digamos ante él su canto, su loanza. Amén por siempre jamás. Fin.» ${ }^{71}$

Entre las fuentes utilizadas por Seadyah ibn Danan sobresale, sin duda alguna, el Sefer ha-Qabbalah de Abraham ben David, que fue la obra de referencia fundamental en toda la cronología hispano-hebrea de fines de la Edad Media y comienzos de la Edad Moderna. Pero una lectura atenta del Ma'amar 'al séder ha-dorot permite descubrir que su autor hizo uso de otras fuentes, como las diversas obras de Maimónides, la Carta del gaón Sherirah a la comunidad de Cairuán ${ }^{72}$, y otros diversos testimonios contemporáneos.

68 Se refiere a su Mishne ha-Torah, obra redactada en los años setenta del siglo xı, y que en sus catorce libros regula la vida judía en su totalidad; con gran claridad, y de forma sistemática, dictamina cómo debe actuar el creyente judio en las más diversas circunstancias. Tuvo una grandísima repercusión en el pensamiento judio medieval.

69 En realidad, nació en el año 1138.

to La muerte de Maimónides se fija, generalmente, en el dia 15 de diciembre de 1204.

71 C. del VAlLe-G. Stemberger, Saadia Ibn Danán. El orden de las generaciones. Seder haDorot, pp. 139-140.

72 Se trata de una obra representativa de las "cadenas de transmisión de la tradición", re dactada a fines del siglo x por el gaón Sherirah ben Hanina ben Yehudah, máxima autoridad rabínica de Pumbedita (Babilonia), en respuesta a las cuestiones planteadas por el sabio Ya'aqob ben Nissim ben Yoshi'ahu en nombre de la comunidad de Cairuán, acerca del modo de redacción de la Mishnah, de la Tosefta, de los Beraytot (Midrash no canónico), de los Midrashim Sifrá y Sifré y del Talmud, y sobre la transmisión de la tradición hasta tiempos contemporáneos. Parece evidente que la herejia caraíta se encuentra en la base de esta consulta. 


\section{LA «CRONISTICA HEBREA LACRIMOSA». LOS RELATOS ACERCA DE LAS PERSECUCIONES DEL PUEBLO JUDIOO}

Como se ha indicado ya con anterioridad, otro género historiográfico propio de la literatura hebrea es el que tiene por objeto relatar las persecuciones y aflicciones sufridas por los judíos a lo largo de la historia, con el fin de reforzarles en la fe y en el sentimiento de "pueblo elegido de Dios".

De este género historiográfico se conservan dos magníficos ejemplos en la literatura hispano-hebrea: el Shebet Yehudah (La Vara de Judá) de Salomón ben Verga y el Emeq ha-Bakha (El valle del llanto) de Yosef ha-Kohén.

\subsection{El Shebet Yehudah (La vara de Judá) de Salomón ben Verga}

\subsubsection{Autoría del Shebet Yehudah}

En la producción historiográfica hispano-hebrea del período de tránsito entre las edades Media y Moderna ocupan un destacado lugar tres miembros de la familia sevillana Ben Verga, a los que se atribuye la elaboración, en mayor o en menor medida, de la crónica titulada Shebet Yehudah (La vara de Judá).

El mayor de ellos, Yehudah ben Verga, sobresalió en la Sevilla de la segunda mitad del siglo xv como astrónomo y matemático y, en menor medida, como cabalista e historiador; incluso parece que actuó en alguna ocasión como representante de la comunidad judía sevillana ante las autoridades cristianas. En los años ochenta emigró a Lisboa, quizás por temor a la Inquisición, ya que, según algunos autores, fue acusado de hacer proselitismo entre los judeoconversos, animándoles a dejar el reino de Castilla para retornar libremente a la religión judia. Murió en Lisboa, en el año 1499, después de haber pasado algún tiempo en prisión con el fin de que delatase a judaizantes.

Además de algunos tratados astronómicos, es posible que, como se indica en el prefacio del Shebet Yehudah, Yehudah ben Verga fuera autor también de una historia sobre las violencias y persecuciones sufridas por los judíos hasta su tiempo, que serviría como punto de partida para la redacción de esta crónica:

"Dice Salomón ben Verga, de bendita memoria: Al final del libro que compuso mi antepasado, el célebre sabio don Jehudah ben Verga - de feliz recordación- encontré anotadas algunas de las violencias y persecuciones que padecieron los israelitas en tierra de infieles, y que yo he traducido para 
que la conozcan y aprendan los hijos de Israel y se conviertan implorando piedad al Señor de las misericordias, de modo que Él, en gracia de lo que sufrieron perdone sus pecados y a sus aflicciones diga: ;Basta!.

Y titulé este libro La vara de Judá; porque éste (Judá), que imperaba en un principio, sintió después sobre sí la vara de su aflicción por el Altísimo, según había predicho el Profeta: Porque se arruinó Jerusalén y se hundió Judá (Isaías, III, 8)» ${ }^{73}$.

En este sentido, algunos autores son de la opinión de que las notas y documentos elaborados por Yehudah constituyen el núcleo del Shebet Yehudah; sin embargo otros, entre los que debe ser destacado Yitzhaq Baer, teniendo en cuenta la unidad en el estilo literario que presenta toda la obra, defienden la tesis de una autoría única, que atribuyen a Salomón ben Verga. Quizás lo más probable es que Salomón utilizara algunas notas redactadas por Yehudah, a las que daría forma literaria en su crónica, o, incluso, que la referencia a Yehudah sea meramente ficticia, con el fin de conferirle mayor autoridad.

Salomón ben Verga, para unos hijo y para otros nieto o sobrino de Yehudah, sería el autor principal del Shebet Yehudah. Sobresalió como médico e historiador, alcanzando gran notoriedad en la aljama hebrea sevillana, por la que fue designado en el año 1487 para llevar a cabo la recaudación de las cantidades que irían destinadas a sufragar el coste del rescate fijado para evitar la cautividad de los judíos de Málaga. La mayor parte de su vida la pasó en el reino de Castilla, por lo que no resulta extraño que la mayoría de los asuntos tratados en el Shebet Yehudah estén localizados en este reino. Pero antes de 1492 emigró a Lisboa -probablemente acompañando a Yehudah-, ciudad en la que residió como converso hasta 1507 cuando, con ocasión de la matanza de criptojudíos que tuvo por escenario la ciudad lisboeta en 1506, se trasladó a Turquía, fijando su residencia en Adrianópolis, ciudad donde nació su hijo Yosef y donde compuso la mayor parte del Shebet Yehudah.

Como el mismo Salomón indica en el capítulo 64, redactó otra obra titulada Shebet ebrató (La vara de su ira), en la que narraría los sufrimientos de los judíos de Toledo, el servicio del Templo por parte de los sacerdotes el día de las expiaciones y la fiesta de la ofrenda (la Pascua), pero ninguna otra noticia de él se ha conservado:

"Sobre el objeto del culto, la ofrenda de la Pascua y su asunto escribió Rabbi Don Manuel en su tiempo, cosas notables en el libro que compuso

73 Chébet Jehuda (La Vara de Judá) de Salomón ben Verga, p. 44 
acerca de las razones de los preceptos. Yo he aducido su relato en mi obra Chébet Ebrató ${ }^{74}$.

La compilación llevada a cabo por Salomón ben Verga fue completada por su hijo Yosef, quien nació y vivió en Adrianópolis en la primera mitad del siglo XVI, ciudad en la que se educó con Yosef al Fezí y donde formó parte del colegio de rabinos. Parece ser autor de una obra titulada Se'erit Yosef (Resto de José), en la que se contienen reglas y observaciones necesarias para una correcta comprensión de ciertas obras talmúdicas ${ }^{75}$. Su colaboración en el Shebet Yehudah fue escasa, limitándose a la inclusión de algunos relatos relativos a la historia de los judíos en Turquía -en los capítulos 11 y 32, así como al final de la crónica-, así como de algún escrito tomado de fuentes latinas.

\subsubsection{Objeto y contenido de la obra}

El Shebet Yehudah consiste en una extensa narración de las persecuciones sufridas por los judíos en diferentes territorios y épocas. En el breve prólogo que precede a la crónica, Salomón ben Verga señala que el propósito de su obra consiste en dar a conocer a los hijos de Israel las aflicciones sufridas en tierra extranjera, a fin de que imploren el favor divino y, en virtud de lo que habían sufrido, el Señor considerara perdonados sus pecados y cesaran sus tribulaciones. El título de la crónica obedece, en palabras del propio autor, a que como había predicho el profeta Isaías, la desgracia cayó también sobre el rey Judá («sintió el azote de la vara del Altísimo") por no cumplir la voluntad de Yahveh:

"Ciertamente se tambaleará Jerusalén y Judá caerá, pues sus palabras y acciones son contrarias a Yahveh, desafiando a su majestad” (Isaias, III, 8).

En definitiva, el objetivo del Shebet Yehudah consiste en propiciar el arrepentimiento de los judíos por la tibieza o el abandono de la fe, con la esperanza de que, de este modo, cesarían todas las penalidades que sufrían en el destierro.

La crónica se estructura en 64 capítulos, la mayor parte de los cuales se corresponden con distintas persecuciones sufridas por los judios a lo largo de la historia. Las que se describen con mayor detalle son las que

74 Chébet Jehuda (La Vara de Judá) de Salomón ben Verga, p. 258.

75 Chébet Jehuda (La Vara de Judá) de Salomón Ben Verga, p. 8. 
tuvieron lugar en España y, en menor medida, en Portugal, que constituyen la más interesante aportación de la obra. Por el contrario, las que acaecieron en áreas geográficas más alejadas sólo se compendian e, incluso, hay algunas importantes persecuciones antijudías que se omiten por completo. Después del capítulo 64 se incluyen varios relatos variados, en algunos de los cuales se refieren también persecuciones llevadas a cabo contra los judíos en diversas localidades.

Pero un simple vistazo al índice analítico del Shebet Yehudah evidencia la falta de un plan general de la obra, así como del más mínimo orden cronológico en los relatos incluidos en ella. De esta forma, el primer capítulo trata sobre la persecución sufrida por los judíos en tiempos del triunviro Marco Antonio (40 a.C.); el capítulo segundo sobre la que tuvo lugar en tiempos de Ben Sira, autor del Eclesiastés (200 a.C.); el tercer capítulo sobre la que acaeció en Persia (303-304 a.C.); y el cuarto capítulo sobre la que promovió Ibn Tumart, caudillo de los almohades (1142 d.C.). Más adelante, si en los capítulos 21 al 27 se narran acontecimientos ocurridos en los siglos XIII y XIV, en los capítulos 30 y 31 el autor retrocede al siglo XII.

Con ocasión del relato de algunas persecuciones, Salomón ben Verga menciona a algunos falsos mesías, e intercala la narración de controversias religiosas acaecidas en el seno de la comunidad hebrea, así como otras de mayor enjundia que habrían tenido lugar entre cristianos y judíos. Pero, salvo la controversia relatada en el capítulo 40, la que tuvo lugar en Tortosa en los años 1413-1414, todas parecen ficticias. Es muy posible que los personajes judíos que aparecen como protagonistas de dichas controversias sean históricos y conocidos por sus contemporáneos, pero la verosimilitud de los hechos narrados y la cronología de los mismos ofrece muchas más dudas; y otro tanto cabe decir de los protagonistas cristianos, quienes en muchos casos parecen personajes fruto de la invención del autor (es el caso del sabio Tomás, quien tiene un papel protagonista en el capítulo séptimo y en dos de los relatos incluidos al final de la obra).

Salomón ben Verga pretende demostrar que el pueblo judío es el que ha sufrido una persecución más violenta y continuada a lo largo de la historia, y trata de averiguar cuáles fueron las causas que la motivaron; este análisis le lleva a desarrollar una auténtica "filosofía de la historia del pueblo judío", que constituye, sin duda alguna, una de sus aportaciones más interesantes. Para el autor del Shebet Yehudah, las persecuciones padecidas por el pueblo judío serían el resultado de la cólera divina por desatender los mandatos de la Ley; porque, como señala el Libro de los Proverbios (III, 11-12): 
"La corrección de Yahveh, hijo mío, no la desprecies, ni tengas aversión a su amonestación;

pues Yahveh recrimina a quien ama y aflige al hijo que le es querido".

El capítulo 63 está dedicado íntegramente a explicar las razones por las que el pueblo judio fue el que más sufrió la cólera divina cuando, precisamente, era el "pueblo elegido" de Dios. Así se expresa Salomón ben Verga:

"Dice Salomón: Cuando alguno haga pasar por su pensamiento estas grandes calamidades, se sorprenderá y dirá: ¿Por qué esta gran cólera no obró asi con ninguno de los otros pueblos, estando ellos más cargados de pecados que los judios? A todas estas y a parecidas preguntas responde un solo versículo que declara: Solamente a vosotros he conocido, etc... (Amós, III, 2). Añadamos a esto siete causas, que han originado lo que nosotros hemos padecido. La primera, los pecados de nuestros padres, como han manifestado nuestros sabios, de bendita memoria, diciendo: $Y$ en el día de mi castigo (castigaré a ellos sus pecados) (Éxodo, XXXII, 34), quiere decir que no se verificará ningún castigo (sin que sea castigado el pecado del becerro de oro). También afirma el poeta elegíaco: Nuestros padres pecaron; pero no ellos, etc...

Segunda. Porque cuando el mérito no es grande, el destierro se sigue por naturaleza, a causa del odio de religión y del deseo del que domina de someter a los otros habitantes del mundo a su religión y su fe. Por eso han dicho también nuestros sabios: ¿por qué se llama aquel monte Sinaí? Porque de alli bajó el odio. Tanto más cuanto que nuestra religión prohibe comer y beber con los no judios, cosas que aproximan los corazones, como lo enseñan nuestros sabios: Grande es la influencia del comer juntos, pues acerca a los distanciados, y como declaran ellos sobre el pasaje: ¿Porque tú lo has hecho.

Tercera. La muerte de Jesús de Nazareth, y no en vano manifestó Moisés: He aqui que sacrificamos al ídolo de Egipto ante sus ojos iy no nos apedrearán? (Éxodo, VIII, 22).

Cuarta. Porque hay tres clases de envidias importantes: la envidia de la religión, la de las mujeres y la de las riquezas, y todas tres se encuentran en Israel con los demás pueblos; pues por el continuo trato ya habían comenzado los judios en España a poner sus ojos en las hijas del país. Algunos se habian permitido esto, afirmando que no habia en ello sino la pena del castigo corporal; y no consideraban que los celosos podian matarlos y que, según las palabras de la Tradición, sigue a una acción tal el castigo de la extirpación. Más sobre todos los pecados está el que, si quedare embarazada la doncella, habría él engendrado un hijo para el culto idólatra. La envidia de las riquezas, porque entraron los judíos en los oficios y negocios de los cristianos y especialmente porque, cuando se halla a un hombre que roba o hurta, echan la culpa a todos ellos, según su costumbre, y resulta una profanación del Nombre divino; pues dicen que no tenemos religión alguna, como escribió $R$. Moseh de Cozzo que, aunque no hubiese sino esto en nuestro pueblo, ello 
bastara a prolongar nuestro destierro. Se declara en una profecia: El resto de Israel no hará injusticia alguna ni pronunciará ninguna mentira.

La quinta causa es que el pueblo se ha habituado a jurar en falso, y escribe Aben Ezra que esto sólo es suficiente para dilatar nuestra proscripción.

La sexta es la soberbia, pues se envanecieron algunos de nuestro pueblo y pensaron mandar sobre los cristianos, los habitantes del país, siendo éstos los señores. A consecuencia de la soberbia ocurrió también en el año de la expulsión, que en la fiesta de la Expiación ${ }^{76}$ se entabló una contienda acerca de los asientos en la sinagoga y cada cual tomó un cirio de los que había ante el Hecal ${ }^{77}$ para pegar a su compañero. Cosas parecidas suceden frecuentemente entre nosotros y verdaderamente justo es el Señor!

Como tales asuntos quebrantan los ánimos, me ha parecido oportuno introducir aquí un asunto alegre, y es la magnificencia del Templo y su edificio, tal como lo hallé escrito por Versoris el grande, a petición del piadoso rey Alfonso; $y$ lo he traducido de la lengua latina a nuestra santa lengua» ${ }^{78}$.

Pero no sólo en el capítulo 63, sino en otros distintos capítulos a lo largo de la obra, Salomón ben Verga se esfuerza por encontrar una justificación al odio que distintos pueblos, y en diferentes momentos históricos, manifestaron hacia los judíos, con su expresión más patente en las persecuciones y en las acusaciones de muy diferente tenor lanzadas contra ellos: crimen ritual, profanación de Hostias consagradas, envenenamiento del agua de pozos, ríos y fuentes para provocar la muerte de los cristianos, etc. Es especialmente interesante a este respecto el capítulo séptimo, en el que, la noticia de un pleito surgido con motivo de una acusación de crimen ritual lanzada contra los judios, da pie al autor para hacer amplias digresiones acerca de las causas del odio generalizado hacia el pueblo de Israel. Las razones señaladas por ben Verga a lo largo de la obra podrían resumirse en las siguientes:

1. Su orgullo, que les llevó a ensoberbecerse y a despreciar a los pueblos con los que convivían, considerando la superioridad de su estirpe dentro del género humano ${ }^{79}$.

\footnotetext{
76 Se trata de la fiesta del Yom Kippur, que se celebra el día 10 del mes de tishri.

77 Así se denomina habitualmente entre los sefardies al Arca Santa donde se guardan los rollos de la Torah en la sinagoga.

78 Chebet Jehuda (La Vara de Judá), de Salomón ben Verga, pp. 218-220.

79 La teoría de la superioridad de los judíos sobre el resto de la humanidad se sustentaba en el mito desarrollado por el tudelano Yehudah ha-Levi (c. 1070-1141) en su obra al-Kuzari, obra apologética y filosófica escrita en árabe en la que, mediante el diálogo entre un supuesto rey de los jázaros, un musulmán, un judío y un cristiano, defiende la superioridad del judaísmo como religión profética y el valor de la experiencia religiosa sobre los argumentos racionales; como intermediario entre el cielo y la tierra, el judio se hallaria tan por encima del hombre como el hombre por encima de la tierra.
} 
2. Su riqueza desmedida, que tenía su manifestación más evidente en el uso de un lujo provacativo, en su enorme capacidad adquisitiva, que les habría llevado a hacerse con la propiedad de las tres cuartas partes de las tierras, y en las malas artes empleadas por los mercaderes judíos, para quienes la religión concluía donde comenzaba la posibilidad de obtener beneficio.

Ben Verga considera que antiguamente, cuando los judíos habian vivido con mayor modestia, no habian recibido acusaciones similares a las que se lanzaban contra ellos en su tiempo.

3. Sus particularidades en los hábitos alimenticios, que resultarian sospechosas para sus convecinos cristianos.

Así, pues, el autor del Shebet Yehudah se muestra muy crítico para con sus correligionarios de su tiempo, de quienes considera que conservarian sólo en muy pequeñas dosis la grandeza del pueblo hebreo de otros tiempos; en este sentido, condena de forma terminante las discordias que se manifestaban en el seno de las comunidades hebreas, poniendo como ejemplo de ellas las frecuentes discusiones por ocupar los bancos de privilegio en las sinagogas (capítulo 63).

Sin embargo, ben Verga se esfuerza por demostrar la falsedad de algunas de las acusaciones más comunmente lanzadas contra los judios, como la que les achacaba la práctica de crímenes rituales con niños cristianos durante la Semana Santa, con el fin de rememorar la crucifixión de Jesucristo y para utilizar su sangre en la preparación de las maz$z o t^{80}$. Teniendo en cuenta las funestas consecuencias que este tipo de acusaciones tuvo para numerosas comunidades hebreas de toda la Europa occidental y central, no resulta extraño que se le dedique a este tema una atención muy especial a lo largo del Shebet Yehudah; así, los capítulos $16,17,29$ y 61 , entre otros, tratan acerca de las tensiones producidas en las relaciones cristiano-judías en diversas localidades con motivo de denuncias de crimen ritual. Ben Verga manifiesta lo absurdo de esta acusación, por cuanto no tendría ningún fundamento que los judíos utilizaran la sangre de cristianos en la elaboración de las mazzot cuando la Torah prohibe terminantemente el consumo de sangre (capítulo 7), y cuestiona el valor de los testimonios arrancados bajo tormento (capítulo 29).

80 Tortas de pan ázimo o cenceño, es decir sin levadura, que consumen los judios durante la Pascua por la prohibición de consumir durante los ocho dias de esta fiesta alimentos fermentados. 
Es también significativo el hecho de que a lo largo de la crónica abunden los relatos en los que reyes, papas y sabios protegen a los judíos, en tanto que es el pueblo quien carga las tintas contra ellos; para ben Verga esta realidad obedecería, básicamente, a que los judíos suplantaban a los cristianos en los oficios hacendísticos, y a que los oprimían económicamente. Asimismo no puede ocultar la profunda aversión que sentía hacia los judeoconversos, lo que le lleva a justificar el odio que los cristianos viejos sentian hacia éstos, afirmando que

“nada aprovechará su cristianización sino, únicamente, para que se ensoberbezcan sobre los verdaderos cristianos, y no teman, porque ya pasan por tales en la apariencia, y no paguen los impuestos reales que entregaban cuando eran judíos" ${ }^{81}$.

Como es habitual en todas las crónicas de época medieval, con frecuencia a lo largo del texto se incluyen relatos fabulosos, en los que los judíos serían librados de un peligro inminente por mediación divina; son cuadros llenos de pasión, reflejo indudable de un profundo fervor religioso. En cualquier caso, los milagros relatados en el Shebet Yehudah no son muy originales: se trata de reyes que persiguen a los judíos y que son derrotados en la batalla -en el capítulo 3 se achacan las desgracias sufridas por el imperio persa sasánida a la persecución que promovió contra los judíos desde los tiempos de Ormuz II (301-309)-, de individuos o de pueblos enteros que mueren de forma súbita y extraña o que sufren algún desastre natural después de haber causado daño a los judíos -en el capítulo 60 se justifica la sequía y la escasez de alimentos sufrida por los lisboetas por la persecución llevada a cabo contra los cristianos nuevos de Lisboa en 1506-, o de dignatarios que reciben una inspiración divina para actuar como protectores del pueblo de Israel. Sirva como ejemplo de estas narraciones el capítulo 61, en el que se relata el milagro practicado por el cabalista Don Shelomoh ha-Leví ante una acusación de crimen ritual:

“He oído que en España algunos lanzaron la calumnia de que habían hallado en casa de un judio un muchacho muerto y mutilado en la parte del corazón, y afirmaron que le habían sacado éste para celebrar con él la fiesta de la Pascua. Mas llegó Don Salomón ha-Leví, que era sabio y cabalista, puso debajo de la lengua del muchacho el nombre de Dios ${ }^{82}$ y despertó aquél, declarando quién le había matado y sacado el corazón para

81 Chébet Jehuda (La Vara de Judá) de Salomón ben Verga, p. 222.

82 Con toda probabilidad, un amuleto con el Tetragrama, es decir las cuatro letras (YHWH) de que se compone el nombre sagrado de Yahveh, al que los judíos en época medieval conferian la facultad de operar milagros. 
calumniar a los infelices judíos. Yo no lo he visto escrito, pero así lo he oído" ${ }^{83}$.

Así, pues, la fantasía ocupa un importante lugar en el manejo del material histórico por parte de Salomón ben Verga, de forma que es frecuente la inclusión de relatos que, con la apariencia de históricos, no son sino cuentos propios de la época o narraciones a las que se da forma de escenas dramáticas. En ocasiones el cronista cae en errores que manifiestan a todas luces to inverosimil del relato, como cuando en el capítulo 12 narra la resolución por parte del rey Manuel I de Portugal de un conflicto acaecido en 1495 en la localidad toledana de Ocaña. Del mismo modo, los debates entre cristianos y judíos que eran presenciados por reyes o por papas, y de los que hay varios ejemplos a lo largo del Shebet Yehudah, son en la mayor parte de los casos puramente fantásticos, y tienen un marcado carácter apologético. A través de ellos cabe deducir el sentimiento de firme convicción de los judios en su religión, lo que dificultó considerablemente los propósitos de las autoridades cristianas, laicas y eclesiásticas, de lograr su conversión al cristianismo.

No obstante, pese a que con frecuencia Salomón ben Verga recurre a personajes libremente inventados y hace referencia a crónicas inexistentes, su pretensión no es la de permanecer en un mundo de fábula; son recursos literarios que emplea para alcanzar su propósito principal, que consiste en explicar el trágico destino secular del pueblo judío, asi como en analizar la situación social de los judíos castellanos y las causas que motivaron su expulsión. De este modo, y pese a la inclusión de relatos inventados por el cronista, los estudiosos del Shebet Yehudah han puesto de manifiesto el trasfondo histórico de buena parte de la obra ${ }^{84}$, y la existencia de un plan preconcebido que guía el relato. Frente a la tesis mantenida por Isidore Loeb, para quien esta crónica consiste en una simple acumulación, sin ningún criterio, de relatos populares recogidos por tres compiladores distintos - Yehudah, Salomón y Yosef ben Verga- ${ }^{85}$, Yitzhak Baer, tras un minucioso análisis del Shebet Yehudah ${ }^{86}$, afirma que la autoría real de la obra corresponde únicamente a Salomón, y llega

83 Chébet Jehuda (La Vara de Judá) de Salomón ben Verga, p. 217.

84 Aunque en ningún caso de la totalidad de la obra, como parece deducirse de ciertas manifestaciones de Meyer Kayserling y de Heinrich Graetz.

85 Isidore LOEB, "Le folklore juif dans la chronique du Schebet Jehuda d'ibn Verga".

86 Fritz BAER, Untersuchungen über Quellen und Komposition des Schebet Jehuda. Berlín. Veröffentlichungen der Akademie für die Wissenschaft des Judentum, 1923. 
a determinar con rigor el límite entre la realidad y la ficción, así como los objetivos que le guían en su elaboración y los métodos historiográficos utilizados, con una particular atención a las fuentes.

\subsubsection{Las fuentes del Shebet Yehudah y su valor como fuente historiográfica ${ }^{87}$}

Como ha puesto de manifiesto Yitzhak Baer, entre las fuentes utilizadas por Salomón ben Verga para la redacción de su crónica ocupa un lugar destacado el Sefer Yosippon (Libro de José). Asimismo, todo parece indicar que ben Verga utilizó también algunas de las obras de Yishaq Abravanel, como el Sefer melaquín, del que tomaria la leyenda que fijaba el establecimiento de los judios en España en los tiempos del rey babilonio Nabucodonosor, la noticia sobre la "Translatio Imperii", o la referencia a las diez calamidades del pueblo hebreo.

Por el contrario, tan sólo se encuentra una referencia a Abraham ben David a lo largo de todo el Shebet Yehudah, lo que hace suponer que su Sefer ha-Qabbalah debió ser utilizado por Salomón ben Verga en mucha menor medida que en las crónicas de Abraham ben Salomón de Torrutiel, Rabí Yosef den Shaddiq de Arévalo, Abraham Zacut y Seadyah ibn Danan. En cualquier caso, hay algunos relatos cuyo origen es difícilmente identificable y que pudieran haber sido tomados de la obra de alguno de estos autores.

Del mismo modo, Baer ha resaltado los notables paralelismos y analogías que pueden observarse entre el Shebet Yehudah y la Consolaçam as tribulaçoes de Israel del portugués Samuel Usque, lo que llevó a algunos autores a apuntar una posible influencia de la obra de ben Verga en la de Usque o la utilización de una fuente común, que para Heinrich Graetz podría ser el Zikrón ha-shemadot (Recuerdo de persecuciones) de Profiat Durán.

Algunas noticias son, sin duda alguna, de origen alemán, por lo que es bastante probable que procedan de relatos que Salomón ben Verga oiría referir a judios alemanes emigrados a Italia. $Y$ no faltan tampoco relatos procedentes de fuentes latinas y musulmanas.

${ }^{87}$ Son fundamentales las páginas que dedica a estas cuestiones Francisco Cantera Burgos en la introducción de su edición del Chébet Jehuda (La Vara de Judá). Granada, 1927, pp. 9-41, y que seguiré en sus líneas generales. 
Por lo tanto, además de las fuentes escritas, ben Verga utilizó también de forma profusa relatos que le fueron transmitidos de forma oral, así como anotaciones sobre sucesos contemporáneos que conoció personalmente y tradiciones recibidas de sus familiares y allegados. El conocimiento directo de los hechos históricos se hace notar en el relato de la suerte que corrieron los judíos y conversos en Portugal (capítulo 60), que narra con profusión de detalles, en tanto que él mismo reconoce (capítulo 52) que sólo conoce por referencias las peripecias de los judíos españoles esparcidos por el Mediterráneo, ya que él se había establecido en Portugal ya con anterioridad a la expulsión de 1492. Por lo que respecta a la situación de los judíos portugueses, no deja de ser llamativo el tratamiento favorable que en el Shebet Yehudah recibe el rey Manuel I el Afortunado, a quien se denomina «rey piadoso", lo que contrasta con otras crónicas judías contemporáneas que lo presentan como enemigo de los judíos; y hasta tal punto llega esto que ben Verga suprime de su crónica el relato de la expulsión de los judíos de Portugal, asi como cualquier referencia a los anussim, o judíos falsamente convertidos al cristianismo, hasta la persecución de 1506. El motivo de esta toma de postura no está claro, ya que si para algunos autores pudiera deberse al rechazo que le provocaría narrar unos acontecimientos en los que él mismo había fingido una conversión al cristianismo, para otros quizás obedecería al intento de rodear de buena fama a un monarca que en los últimos años de su reinado persiguió con dureza a los anussim.

En definitiva, y pese a que el Shebet Yehudah es una obra algo desigual, no cabe la menor duda de que, desde el punto de vista historiográfi$\mathrm{co}$, es una de las producciones de mayor calidad dentro del género cronístico hebreo, y su autor es, junto con Abraham ben David y el portugués Samuel Usque, el cronista hispano-judío más original.

Se trata de una obra que refleja perfectamente el esplendor de la cultura judía en el pasado, pero que es también signo de un tiempo nuevo, de un tiempo marcado por el tránsito del Medievo al Renacimiento y presagio de una nueva era en la cultura judaica. Su contribución a la literatura hebrea es de fundamental importancia, por cuanto es la primera obra en la que se ofrece una perspectiva histórica del "problema judío", analizando con detalle sus vertientes económica, social y propiamente humana.

Son también interesantísimos algunos apuntes de "psicología social" que afloran de una lectura atenta del Shebet Yehudah, y que sirven para enfocar con nitidez un tema de tanto interés como es el relativo a la «imagen de los judíos" en época medieval, así como para profundizar en el análisis de la actitud de los judios - en particular de la intelectualidad 
hebrea de épocas medieval y moderna- ante la difusión de esa imagen peyorativa ${ }^{88}$.

El capítulo séptimo es particularmente interesante a este respecto; consiste en un amplio debate entre un sabio cristiano llamado Tomás, personaje desconocido que aparece en otros capítulos de la obra, y un rey Alfonso de Sefarad, al que no es posible identificar con exactitud con ningún monarca castellano, pues los relatos que se suceden a lo largo del capítulo corresponden a distintos períodos históricos ${ }^{89}$. El rey Alfonso llama al palacio real al sabio Tomás con el fin de solicitar su consejo acerca de una denuncia formulada contra los judíos: unos días antes un obispo había predicado ante la multitud que los judíos sólo podian celebrar la fiesta de la Pascua con la sangre de un cristiano, con la que prepararían las mazzot, lo que movió al pueblo a reclamar la justicia del rey contra ellos. El largo e interesante debate entre el monarca y el sabio permite a ben Verga profundizar en torno a unos supuestos rasgos genéricos definitorios del carácter hebreo para, desvirtuando algunos de ellos -crueldad y perfidia- o admitiendo otros - cobardía, pertinacia en la fe, soberbia y orgullo, inteligencia y sagacidad, solidaridad-, negar las acusaciones que se lanzaban contra los judíos y que ponían en serio peligro su integridad física. Es también significativa la diferencia que establece entre el carácter y la actitud del pueblo judio en la antigüedad, marcado por virtudes como la valentía y la fortaleza, la inteligencia y la sagacidad, o la solidaridad, y en su tiempo, cuando serían rasgos dominantes en el pueblo hebreo la cobardía de espíritu y la falta de solidaridad. Condena también sin paliativos algunas actitudes de sus contemporáneos que, en su opinión, acrecentaban el odio y la envidia de los cristianos hacia ellos: la arrogancia frente a la humildad, o el lujo frente a la austeridad.

La lectura atenta de otros capítulos del Shebet Yehudah permite detectar también otras acusaciones antijudías que debían estar muy extendidas entre el pueblo castellano a fines de la Edad Media, y que el cronista trata de desvirtuar. Considera, de este modo, que estaba comúnmente extendido entre los cristianos que el rechazo por parte de los judíos del

88 Véase sobre este particular mi trabajo titulado «Negación de la 'imagen del judio' en la intelectualidad hispano-hebrea medieval: el ejemplo del Shebet Yehudah", en Aragón en la Edad Media, XIV-XV (1999), pp. 263-274.

89 A. SOHET (A. SOHET - Y. BAER, Selomoh ibn Verga. Sefer Sebet Jehuda, Jerusalem, 1947, p. 170) y María José Cano (SELOMOH IBN VERGA, La Vara de Yehudah (Sefer Sebet Yehudah). Introducción, traducción y notas por Maria José Cano, p. 35, nota 2) lo identifican con Alfonso X el Sabio, y F. Cantera, siguiendo a Isidore Loeb, con Juan II de Castilla (F. CANTERA, Chebet Jehuda (La Vara de Judá), pp. 91 y 92, nota 3). 
vino elaborado por cristianos sería motivado por un profundo desprecio hacia éstos; que su terquedad y sutileza en los debates y polémicas religiosas se sustentarían con frecuencia en la mentira; o que los judíos habrían difundido la peste por el mundo aprovechando que eran inmunes a ella, lo que estaría en estrecha relación para los acusadores con la práctica de la magia y la brujería.

Por otra parte, es también destacable de esta crónica la extraordinaria riqueza onomástica y de topónimos que ofrece, así como las abundantes referencias acerca de costumbres y prácticas propias de los judíos; también contiene algunos cuentos populares de origen hebreo, que permiten reconstruir facetas poco conocidas del folclore judío sefardí.

Por último, otro de los grandes valores del Shebet Yehudah es su estilo literario, claro y cuidado, muy en consonancia con el estilo bíblico al que parece que quiere imitar, de forma que es bastante frecuente el engarce de frases escriturarias. Son también dignas de tener en cuenta algunas descripciones particularmente dramáticas y emotivas; así, aunque algunos de los relatos acerca de persecuciones antijudías ya figuran en otras crónicas hebreas, anteriores en el tiempo o contemporáneas del Shebet Yehudah, en esta crónica son narradas con mayor viveza, con más detalles, con un tono más espiritual y, al mismo tiempo, con un sabor legendario que hace mucho más amena su lectura.

El relato se enriquece con animadas narraciones acerca de disputas dialécticas mantenidas entre cristianos y judíos (capítulos $7,8,64,65$ ), y a lo largo de la obra es fácil descubrir determinadas figuras convencionales o personajes-tipo, como reyes -en particular, el rey «Alfonso de España»-, papas y sabios que se muestran escépticos con las acusaciones lanzadas contra los judios y que los defienden frente a los ataques populares, en muchos casos promovidos por predicadores exaltados (capítulos 7,14 ); en el extremo opuesto, no son raros tampoco los arquetipos de princesas necias e interesadas que se muestran contrarias a los hebreos (capitulo 14), o apóstatas judios llenos de odio hacia sus antiguos correligionarios. Asimismo pueden apreciarse a lo largo de la obra, y en diferentes momentos, toques de ironía o de desesperanza que desbordan el típico cuadro de la cronística medieval, y que nos introducen ya en el mundo del Renacimiento.

En definitiva, las numerosas ediciones impresas que se hicieron de esta obra, así como las múltiples traducciones a muy distintas lenguas y las frecuentes citas que del Shebet Yehudah se encuentran en la historiografía hebrea de época moderna, son pruebas evidentes de la alta estima en que siempre se ha tenido por parte de los estudiosos e investigadores de la historia judía, y del interés que su lectura ha suscitado. 


\subsection{El Emeq ha-Bakha (El valle del llanto) de Yosef ha-Kohén}

\subsubsection{El autor ${ }^{90}$}

Los datos conocidos acerca de la biografía de Yosef ha-Kohén se contienen, en su mayor parte, en diversos capítulos del Emeq ha-Bakha (El valle del llanto). Nació en el año 1496 en Avignon (capítulo 133), ciudad en la que habían contraído matrimonio sus padres, quienes salieron con sus respectivas familias del reino de Castilla en 1492 como consecuencia de la promulgación del edicto de expulsión (capítulo 119). Su familia paterna era originaria de Cuenca, pero tras las persecuciones de 1391 se trasladó a la localidad conquense de Huete (capítulo 90). En 1501 su familia se estableció en Génova (capítulo 133), ciudad en la que Yosef vivió buena parte de su vida, ejerciendo profesionalmente como médico y ocupando un destacado lugar en su comunidad hebrea. En 1550, al ser expulsados los judíos de Génova, se trasladó a Voltaggio, donde fue nombrado médico oficial de esta localidad (capítulo 161); en 1567, y por idéntico motivo, se estableció en Castelleto de Monferrato (capítulo 192), desde donde regresó a Génova en 1572, ciudad en la que falleció tres años después.

Yosef ha-Kohén poseía una vasta formación intelectual, que le permitió cultivar diversos campos de la actividad científica y literaria; su dominio de diversos idiomas — castellano, portugués, francés, italiano, latín y hebreole posibilitó la utilización de fuentes de muy diversa procedencia, en sus versiones originales. Además de la historia, dedicó también su atención de forma preferente a la gramática y a la poesía.

\subsubsection{La producción historiográfica de Yosef ha-Kohén. \\ El Emeq ha-Bakha (El valle del Ilanto)}

La primera aportación conocida de ha-Kohén al género historiográfico es la obra titulada Dibré ha-yamim lemalké Sarfat we-malké bet otoman ha-tugar (Crónica de los reyes de Francia y de los sultanes otomanos). Su finalidad consiste en narrar las penalidades sufridas por los judíos en tierras de gentiles pero, luego, rebasa su objetivo inicial y se transforma en una especie de ensayo de historia general, ya que da cabida a otros

90 Son muy interesantes las páginas que dedica a la figura humana y a la producción historiográfica de Yosef ha-Kohén Pilar León Tello en su magnífica edición de El valle del llanto (Emeq ha-Bakha). Crónica hebrea del siglo xvı. Introducción, traducción y notas por Pilar León Tello. Barcelona. Riopiedras Ediciones, 1989, pp. 9-35, y que aqui seguiré en sus líneas generales. 
muchos hechos históricos no protagonizados directamente por judíos; supone, así, un progreso considerable en relación a los cronistas hebreos contemporáneos. La obra, impresa por primera vez en 1533, concluía con la quema del Talmud ordenada por el papa Julio III en 1555; pero más tarde la prolongó hasta 1575, año de su muerte, con unos capítulos adicionales que conforman su tercera parte.

Algún tiempo después de dar a la imprenta su primera obra de contenido historiográfico, Yosef ha-Kohén se propuso llevar a cabo una recopilación de las persecuciones y de los sufrimientos padecidos por los judios a través de los siglos y en las más diversas áreas geográficas. Esta obra, a la que dio por título Emeq ha-Bakha (El valle del llanto), se inicia en los tiempos de la destrucción del segundo Templo de Jerusalén y concluye en el año 1574/1575; en una primera edición llegaba hasta el año 1563, año en que fue entregada a la imprenta. Como señala el propio autor en una especie de prefacio, la finalidad perseguida es reunir los relatos acerca de los padecimientos del pueblo hebreo con el fin de instruir al lector y fortalecerle en la fe:

"Palabras de Yosef ben Yehoshua ben Meir ben Yehudá ben Yehoshua
ben Yehudá ben Moshé de la familia de los Kohén, originario de Huete, tierra
de España: puesto que las calamidades que nos han sobrevenido desde el
día de la expulsión de Judá de su tierra hasta hoy, están desparramadas aquí
y allá, me he propuesto reunirlas en una obrita que contenga lo que he en-
contrado en los cuadernos de autores que escribieron antes que yo en lengua
hebrea, y en los libros de ellos (los cristianos). Le he puesto el nombre de
"Valle del llanto" porque, tal como dice su título, así es; pues todo el que la lea
tendrá la respiración jadeante y sus párpados derramarán lágrimas y pondrá
la mano sobre sus riñones diciendo: ¿hasta cuándo, oh Yahveh?; a mi Dios
suplico terminen los días de nuestra aflicción y envíe al Mesías nuestro
Salvador y nos libre sin tardanza a causa de su misericordia. Amén, amén»"

Pasajes enteros del Dibré ha-yamim lemalké Sarfat we-malké bet otoman ha-tugar pasaron íntegros al Emeq ha-Bakha, en particular todas las referencias autobiográficas (capítulos $90,119,133,148,150,159,161,178,185$ y 192).

En cuanto a las fuentes utilizadas en la elaboración de esta crónica, todo parece indicar que Yosef ha-Kohén empleó de forma profusa la crónica titulada Consolaçam as tribulaçoes de Israel (1553), de la que es autor el judío de origen portugués Samuel Usque, y de la que, muy probablemente, tomó la mayor parte de los relatos referidos a los judíos españoles; algunos de los relatos incluidos por Usque en su crónica proceden, a su

91 Yosef HA-KoHen, El valle del llanto (Emeq ha-Bakha), p. 39. 
vez, del Fortalitium fidei de fray Alonso de Espina, de donde los tomó con el fin de rebatir las acusaciones que en esta obra se lanzaban contra los judíos. Por el contrario, no se aprecian semejanzas significativas entre el Shebet Yehudah y el Emeq ha-Bakha, lo que hace pensar en que haKohén no utilizó como fuente la crónica de Salomón ben Verga, muy probablemente porque ni siquiera la conoció.

Ha-Kohén cita también a otros autores judíos que le habrían servido como referencia para diversos capítulos de la crónica: Eliezer ben Natan ha-Levi y Efraim bar Ya'aqob de Bonn para las Cruzadas (capítulos 23, 24, 32, 43, 54 y 64); Rabí Menahem ben Aharon ibn Zerah (1310-ca1385) para el asalto a la judería navarra de Estella en 1328 (capítulo 81) y para las persecuciones contra los judios toledanos a la muerte de Pedro I de Castilla (capítulo 86); Rabí Hayyim Gallipapa para el relato de las consecuencias que para las comunidades hebreas tuvo la epidemia de peste negra de 1348 (capítulos 82 y 84); o Abigedor Kara para la matanza sufrida por los judíos de Praga en 1389 (capítulo 88). Entre los cronistas hispano-judíos tan sólo menciona en una ocasión a Abraham ben David (capítulo 51); y en dos ocasiones hace referencia a la crónica de Samuel Usque, al que cita como "el portugués" (capítulos 80 y 84). Entre los autores no judíos sobresalen las referencias a Sebastián Münster, autor de la Cosmographia Universalis (Basilea, 1550) (capítulos 73, 74, 76, 80 y 84), y a Almanzi, "el aditor», autor de un manuscrito citado en varias ocasiones (capítulos 80, 86, 114, 156, 160, 166 y 178).

Los relatos más interesantes son aquellos en los que Yosef ha-Kohén narra acontecimientos vividos por él directamente, y muy en particular todos los que tienen por escenario la península Itálica. Así, no cabe ninuna duda de que el Emeq ha-Bakha es una obra de importancia fundamental para el conocimiento de las comunidades hebreas de la Italia del siglo XVI.

A lo largo de su crónica, ha-Kohén da pruebas abundantes de un marcado sefardismo, que no sólo se manifiesta en la mayor atención que presta a las comunidades hebreas sefardies que a las ashkenazíes - lo que, indudablemente, guarda relación con el mayor conocimiento que tenía de ellas--, sino, de forma muy especial, en la mayor simpatía que muestra en sus relatos por los protagonistas sefardíes que por los ashkenazíes. Así, entre los conversos a los que se acusa de causar con sus difamaciones la perdición de numerosas comunidades hebreas italianas -destierros, quema de libros y objetos litúrgicos sagrados-, abundan más los de origen ashkenazí que los de origen sefardí:

"También los ciudadanos de Worms expulsaron a los judíos de la ciudad en aquella época y tuvieron que irse a habitar, hasta el presente, donde en- 
contraban. En aquel año llegó alli un judío alemán, hombre perverso, que antes en Israel era Yehudá de Módena, jsea borrado su nombrel, predicó la rebelión contra los judíos y les cogieron en Praga todos los libros sagrados, $e$ incluso los libros de oraciones, requisó por completo, no dejando ni rastro entonces: los llevaron en carros a la corte imperial que estaba en Viena, porque no se habia determinado lo que se había de hacer con ellos" ${ }^{92}$.

La obra la concluye ha-Kohén en el año 1574/1575, poco antes de su muerte, con un breve epílogo en el que da gracias a Dios por haberle animado a escribirla y solicita la gracia y la misericordia divinas:

"Dice Yosef hijo de rabí Yehosu'a ha-Kohen, de bendita memoria: alabo al Señor que me ha decidido a componer esta pequeña recopilación de la mayor parte de las calamidades y turbaciones que nos han sobrevenido desde los días de la destrucción hasta hoy, según ha encontrado mi mano aquí y allá.

Fue terminada el día 21 de tammuz del 5335. Así me asista Yahveh por su misericordia continuamente, y me haga digno de escribir la venida del Salvador y se cumpla en nosotros el versículo: 'regocijaos vosotros alegremente todos los que habéis sufrido por su causa, y termínense los dias de nuestro duelo' (Isaias, LXVI, 10). Amén, amén»" ${ }^{93}$.

Un autor anónimo, autodenominado el Corrector, añadió algunas noticias sin mayor importancia a la primera edición del Emeq ha-Bakha de 1563, y un apéndice en el que se relatan sucesos acaecidos entre 1563 y 1605, dando la impresión de que no conocía la segunda edición de la crónica, la de 1574/1575. Al comienzo de su apéndice explica los motivos que le mueven a su redacción:

«Palabras del Corrector: El primer péreq del Tratado del sábado dice: Los Rabinos enseñaron: ¿quién escribió el libro del ayuno? Hasmania y sus colegas, que eran amigos de las adversidades. Dice rabí ben Gamaliel: aunque amemos las desgracias, pero ¿qué vamos a hacer? Pues si intentásemos consignarlas por escrito no acabariamos. Por esto se me ha ocurrido consignar en un libro los sucesos posteriores a la Crónica de este Josefo, desde aquel día hasta ahora para cumplir lo que se nos ha ordenado: a fin de que lo cuentes en los oídos de tu hijo y de tu nieto (Éxodo, X, 2) ${ }^{94}$.

Teniendo en cuenta la abundancia de referencias a asuntos hispanos en el apéndice del Emeq ha-Bakha, todo permite suponer que el «Corrector»

92 Yosef HA-KOHEN, El valle del llanto (Emeq ha-Bakha), p. 160

93 YoSef HA-KoHeN, El valle del llanto (Emeq ha-Bakha), p. 172.

94 YOSEF HA-KOHEN, El valle del llanto (Emeq ha-Bakha), p. 173. 
sea también de origen español; residía en la ciudad italiana de Lodi, de donde tuvo que emigrar en el año 1597 al decretarse la expulsión de los judíos del Milanesado (capítulo 239). Como Yosef ha-Kohén, demuestra un buen conocimiento de numerosos pormenores relativos a la monarquía española del siglo XVI, si bien la preponderancia absoluta es acerca de cuestiones que afectan a la vida de las comunidades hebreas italianas.

\subsubsection{El estilo historiográfico de Yosef ha-Kohén}

Una de las características más destacables de ha-Kohén en su faceta de historiador es la minuciosidad en su tarea de acopio documental, que no limitaba de forma exclusiva a la consulta de las fuentes escritas; así, para los acontecimientos más recientes buscaba informes a través de conocidos suyos que residían en otros territorios, y consultaba con viajeros extranjeros que pasaban por Italia, por entonces zona privilegiada de confluencia entre Oriente y Occidente. De este modo, cuando narra hechos históricos que conoce directamente o para los que dispone de fuentes fidedignas, el Emeq ha-Bakha es una fuente de información muy fiable; del mismo modo, cuando trata acerca de acontecimientos lejanos en el tiempo - acaecidos en regiones distantes, acude siempre a las fuentes que considera más fiables y no añade interpolaciones propias. En su tarea de elaboración de los originales, el autor introducía con frecuencia notas nuevas, que más tarde pasaban al texto definitivo.

A lo largo de su producción historiográfica, es también fácil advertir su profunda religiosidad; de este modo, achaca a una maldición divina las desgracias que sufren algunas figuras destacadas que se habian mostrado especialmente contrarias a los intereses de la comunidad hebrea: así, se muestra despiadado con los Reyes Católicos, mostrando su complacencia ante la muerte de sus hijos y de la reina Isabel (capitulo 120), y celebra la caída de la poderosa familia romana de los Caraffa (capítulo 184), así como la muerte de los papas Julio III (capítulo 168) y Paulo IV (capítulo 181). De este modo celebra la muerte del papa Julio III:

“Estallad montañas sones de alegria, porque ha muerto el pontífice Julio del Monte, el que tenía la intención de perdernos, el que mandó quemar los libros de nuestra gloria, el 21 de marzo de 5315, que es el $1555^{95}$.

¡Por favor, Señor, Dios del espíritu de toda carne, su gusano no muera y su fuego no se extinga y sirva de oprobio a todo humano! (Isaías, LXVI, 24)" ${ }^{96}$.

95 Se refiere a la quema del Talmud ordenada por el papa Julio III poco antes de su muerte.

96 YOSEF HA-KoHEN, El valle del llanto (Emeq ha-Bakha), pp. 149-150. 
Pese a esta actitud revanchista para con determinados personajes históricos y a las maldiciones más o menos formularias que introduce en sus relatos, la postura de ha-Kohén es menos virulenta hacia el cristianismo y las autoridades cristianas en general que la de otros cronistas hispano-cristianos que, como Abraham Zacut, habían vivido la expulsión de España y habían sufrido en sus carnes las consecuencias más inmediatas del exilio.

Pese a que el sentimiento religioso impregna toda su obra, y quizás precisamente por ello, procura evitar toda referencia a las controversias religiosas propias del judaísmo, y adopta una actitud de cautela en relación con el fenómeno del mesianismo, tan extendido por todo el mundo judío a fines de la Edad Media y en los primeros tiempos de la Modernidad.

Su estilo literario está marcado por la claridad en la redacción, por la concisión del relato, y por el uso de un hebreo clásico muy depurado, utilizando frecuentemente giros y citas bíblicas. Como el Shebet Yehudah, el Emeq ha-Bakha es una obra de lectura fácil y amena.

\section{LOS LIBROS DE VIAJES (SEFER MASA'OT). EL SEFER MASA'OT SHEL RABBI BINYAMIM (LIBRO DE VIAJES DE RABI BENJAMÍN DE TUDELA)}

Dentro del género historiográfico hay que dedicar también atención a los itinerarios o libros de viajes (Sefer Masa'ot), en los que se encuentra abundante información de carácter geográfico, así como también para el análisis de otros múltiples aspectos relativos a la historia política, económico-social, religiosa y cultural.

Entre los escritos de contenido histórico-geográfico de los que son autores judíos españoles merecen ser destacadas las cartas intercambiadas entre Hasday ibn Shaprut (915-970), quien fue consejero político del califa cordobés Abd al-Rahmán III, y Yosef, rey de los jázaros ${ }^{97}$, que contienen datos de indudable interés para el mejor conocimiento de la historia andalusí en el siglo $x$.

Pero, sin duda alguna, el más destacado libro de viajes de la literatura hispano-hebrea es el Séfer Masa'ot shel Rabbi Binyamim (Libro de viajes de Rabí Benjamín), cuyo protagonista es el judío tudelano así llamado,

97 Los jázaros, pueblo de origen turco, entre los siglos vil y $x$ se establecieron en el curso bajo del río Volga, donde fundaron un reino poderoso, hasta su desaparición en el año 969 tras la conquista de su capital, Itil, por los rusos. Se convirtieron en bloque al judaísmo. 
nacido alrededor del año 1130. Rabí Benjamín fue un hombre culto que, además del castellano, dominaba el hebreo y el arameo, y entendía el árabe y el latín y, quizás, el griego. Era asimismo experto en cuestiones bíblicas y talmúdicas, 10 que queda de manifiesto en las frecuentes referencias que a lo largo de su obra se hacen a los libros sagrados del judaísmo. También debía poseer conocimientos acerca de la historia de la Antigüedad clásica, de forma que en diversos momentos de su relato cita con bastante exactitud histórica a varios emperadores romanos y se refiere a hechos relacionados con la historia de Grecia y Roma antiguas.

Pero como señala José Ramón Magdalena en la introducción a su excelente edición de esta obra, todo invita a pensar que Benjamín de Tudela se limitó a dejar un informe o unas notas acerca de su viaje, que servirían al prologuista anónimo para redactar el libro en la versión que nos es conocida ${ }^{98}$. Dice el prólogo lo siguiente:

"Este es el libro de viajes que redactó $R$. Benjamín bar Jonás, del país de Navarra. R. Benjamín salió de su lugar, de la ciudad de Tudela, y marchó y fue a muchos países lejanos, tal como relata en su libro; en cada lugar que entró escribió todas las cosas que vio y oyó de boca de hombres veraces, (cosas) que no habian sido oídas en tierras de España. De este modo hace mención de algunos sabios y príncipes (judíos) de cada lugar. $Y$ trájose consigo este libro a su regreso a tierras de Castilla en el año cuatro mil novecientos treinta y tres (1173).

Y él, R. Benjamín, (era) hombre inteligente e ilustrado, versado en la Torá y en la Halajá, y todas las cosas verificadas para comprobar sus palabras fueron encontradas correctas, exactas e irrefutables, pues él (era) hombre veraz" ${ }^{99}$.

El itinerario seguido por Rabí Benjamín fue, a grandes rasgos, el siguiente 100: de Tudela se dirigió a Zaragoza, desde donde, siguiendo la ruta del río Ebro, llegó a Tortosa, para, a través de Barcelona y Gerona, pasar al Rosellón y Provenza; desde Marsella llegó en barco a Génova, y tras recorrer diversas ciudades italianas, embarcó en Otranto con rumbo a Corfú y Arta.

Ya en territorio bizantino, visitó Constantinopla y varias islas del mar Egeo, y se dirigió luego a Palestina, por entonces bajo dominio de los reinos francos, dejándonos un pormenorizado relato de su estancia en Tierra

98 Libro de Viajes de Benjamin de Tudela. Versión castellana, introducción y notas por José Ramón Magdalena Nom de Deu. Barcelona. Riopiedras Ediciones, 1989, pp. 14-15.

99 Libro de Viajes de Benjamin de Tudela, p. 55.

100 En la edición del Libro de viajes de Rabí Benjamín preparada por José Ramón Magdalena se incluyen unos mapas muy clarificadores acerca del itinerario seguido por el autor. 
Santa. Posteriormente visitó Damasco y Bagdad, ciudad ésta en la que permaneció durante largo tiempo y desde la que realizó varios viajes de más corto radio.

No parece probable que llegara a visitar tierras del Lejano Oriente, como Ceilán o China, de forma que las noticias que sobre estas regiones se ofrecen en su libro, en algún caso claramente fabulosas y con frecuencia carentes de realismo, proceden de relatos y de fuentes indirectas.

El regreso lo realizó a través de Egipto, embarcando en Alejandría con rumbo a Sicilia, desde donde pasó a Roma. Desde aquí, y a través de Luca y Verdún, llegó a París, ciudad donde se pone fin al relato. Pero antes de concluir se hace referencia a diversas comunidades hebreas del valle del Rhin, de Bohemia, de "Esclavonia» O Eslavonia (norte de Croacia) y de Rusia, lo que es posible que obedezca al deseo de dar a conocer la ruta mercantil centroeuropea, especializada en pieles y esclavos, lo que abonaría la tesis de una finalidad comercial del viaje. Su llegada a Tudela tendría lugar en el año 1172 ó 1173, muriendo unos años más tarde, probablemente en el año 1175.

Por lo que respecta a los motivos que llevaron a Benjamín de Tudela a emprender un viaje de tales proporciones, José Ramón Magdalena es de la opinión de que la finalidad fue, muy probablemente, de tipo mercantil, tanto por el itinerario seguido -si se hubiera tratado de un viaje exclusivamente de peregrinación a Jerusalén no tendría justificación la visita a las islas del mar Egeo y a las tierras del Imperio bizantino-como por el muy especial interés que el autor muestra por las especialidades económicas de las ciudades y regiones visitadas, demostrando poseer un buen conocimiento acerca de determinados productos comerciales, como las especias, los objetos de orfebrería y los tejidos de lujo ${ }^{101}$. Lo más probable es que, tratándose de un viaje con una finalidad principalmente comercial, Rabí Benjamín lo aprovechara para visitar los Lugares Santos del judaísmo.

A lo largo de todo el libro, y en la narración de su visita a las más diferentes regiones y ciudades, el autor se interesa, principalmente, por tres tipos de cuestiones:

1. Por las comunidades hebreas de las ciudades que visita, indicando siempre su volumen demográfico, así como el nombre de las autoridades rabínicas, y haciendo algún comentario, más o menos extenso, acerca de

101 Libro de viajes de Benjamin de Tudela, introducción de José Ramón Magdalena, pp. 33-36. 
las condiciones de vida, las actividades socio-profesionales y el nivel cultural y religioso de quienes formaban parte de ellas. En algunas ocasiones cita también a las comunidades judías heréticas, como los epicúreos de Chipre, los caraítas o los samaritanos; cuando se refiere a los judíos ortodoxos habla simplemente de “judíos» o de «rabanitas», en tanto que a los considerados herejes los denomina por el nombre de la secta. Así se refiere a la comunidad hebrea que residia en Constantinopla:

"Y los judios no están en la ciudad, junto a ellos, porque fueron deportados a la otra parte del brazo de mar. Estando rodeados por el brazo (del mar de Mármara), por un lado, no pueden salir a comerciar con los habitantes de la ciudad, sino a través del mar. Hay allí como unos dos mil judíos rabanitas y como unos quinientos caraítas por otra parte; entre éstos y los rabanitas media una barrera. Hay asimismo sabios, a cuya cabeza están: el maestro R. Abtalión, R. Obadia, R. Aarón Bejor Suro, R. José Sir Niro y R. Eliaquim el administrador. Entre ellos hay artesanos sederos, muchos comerciantes y muchos potentados. Alli no está permitido a los judíos montar a caballo, excepto a R. Salomón el egipcio, que es médico del rey. Gracias a él encuentran los judíos gran alivio en su opresión, pues permanecen gravemente oprimidos. Grande es el odio que les tienen los curtidores de pieles, quienes vierten sus aguas pestilentes en las calles, frente a las puertas de sus casas y ensucian el recinto de los judios. Por eso los griegos detestan a los judíos, ya sean buenos o malos, agravando su injusticia sobre ellos. Los judíos son, sin embargo, ricos y buenos, caritativos y cumplidores de los preceptos, soportando la iniquidad de su opresión resignadamente. El nombre del lugar que habitan los judíos es Pera» ${ }^{102 .}$

Del mismo modo, relata con particular minuciosidad todos los detalles relativos a su paso por Palestina, entre ellos los accidentes orográficos relacionados con la historia biblica o postbíblica del pueblo de Israel, como los montes Sinaí y Carmelo, o la cueva de Elías en este último monte.

2. Benjamín de Tudela presta asimismo atención a las grandes líneas de la política nacional e internacional, tanto por lo que respecta al mundo cristiano como al islámico. Así, se interesa por el poder de los estados cruzados y hace referencia a las fuerzas de que disponían las órdenes del Hospital y del Temple; explica la compleja situación política del mundo musulmán, en el que por entonces sobresalía el imperio de los turcos seldyúcidas, extendido por Persia y Mesopotamia; y hace hincapié en algunos síntomas de debilidad en el imperio bizantino, como la necesidad de recurrir a mercenarios extranjeros por la que considera debilidad de carácter de los griegos:

102 Libro de Viajes de Benjamín de Tudela, p. 69. 
«El país es muy pródigo en toda clase de ropas, así como abundante en carne y vino. No se ha visto tal riqueza en ningún (otro) país. Alli son muy sabios en toda la literatura de los griegos. Cada cual come y bebe bajo su parra e higuera. Reclutan mercenarios de todos los pueblos gentiles llamados bárbaros, para guerrear con el sultán Masud, rey de los turcomanos, llamados turcos, porque ellos carecen de espíritu combativo; se les considera, por tanto, afeminados que carecen de fuerza para resistir» ${ }^{103}$.

3. Por último, se interesa también por los grandes centros de producción artesanal y de comercio de Occidente y Oriente, así como por las principales rutas mercantiles. De este modo, señala la distancia que separa entre sí las ciudades que visita, las ventajas e inconvenientes de los puertos, la seguridad o inseguridad de las rutas terrestres o marítimas, o las dificultades que causan las particulares condiciones del medio geográfico:

“Desde allí (desde Sarepta, que pertenece a Sidón) hay media jornada hasta Tiro la Nueva; es ciudad muy buena, su puerto está dentro de la ciudad, pasando los barcos por en medio de dos torres. Por la noche, los aduaneros echan una cadena de hierro entre torre y torre y nadie puede salir, ni en embarcación ni de ninguna manera, para robar algo de los barcos durante la noche. No se encuentra un puerto como éste en todo el país. Es una ciudad hermosa y alberga como a unos quinientos judíos; entre ellos hay sabios en el Talmud, a cuya cabeza están: R. Efraín de Sad, juez, R. Me'ir de Carcasona, R. Abrahán, el jefe de la comunidad. Allí poseen los judíos embarcaciones en el mar; asimismo hay alli judíos artesanos del mejor vidrio, llamado vidrio de Tiro, el (más) estimado en todos los países. También allí se encuentra el mejor azúcar, porque lo siembran, y acuden de todos los países a comprarlo. Subiendo por la muralla de Tiro la Nueva se ve Tiro la Antigua, que está cubierta por el mar: está alejada de Tiro la Nueva como a tiro de piedra. Si se quiere ir en barca, por el mar, se ven las torres, los zocos, las plazas y los palacios en el fondo del mar. Tiro la Nueva es ciudad comercial, viniendo a ella (gentes) de todo lugar 2104 .

Con frecuencia hace una descripción, más o menos detallada, de las ciudades más importantes de su itinerario, informando acerca de sus murallas y monumentos, de su trazado urbanístico, del carácter pacífico o belicoso de sus habitantes, de sus actividades económicas y costumbres, así como de otras cuestiones relativas a fiscalidad o a beneficencia. Nuevamente sirve de ejemplo la descripción que se hace de la ciudad de Constantinopla:

«El perímetro de la ciudad de Constantinopla es de diez y ocho millas, la mitad sobre el mar y la (otra) mitad sobre el continente. Se asienta sobre dos

103 Libro de Viajes de Benjamín de Tudela, p. 69.

104 Libro de viajes de Benjamin de Tudela, pp. 72-73. 
brazos (de mar): uno que viene del mar de Rusia y el otro del mar de España. Vienen (aquí) todos los mercaderes de Babel y de todo el pais de Sinar, de Persia y de Media, de todo el reino de Egipto, de la tierra de Canaán, del reino de Rusia, de Hungria, de Patzinakia, de Jazaria, del pais de Lombardía y de España.

Es una bulliciosa ciudad; a ella vienen con mercadería desde todos los países maritimos y continentales. No hay como ella en ningún país, excepto Bagdad, la gran ciudad de los ismaelitas. Alli está la iglesia de Santa Sofía, así como el Papa de los griegos, ya que (éstos) no profesan la religión del papa de Roma. Hay allí tantas iglesias como número de días tiene el año, y una incalculable cantidad de dinero que anualmente traen, como impuesto, de las dos islas, de las fortalezas y de las grandes capitales que hay alli. Riqueza tal no se encuentra en ninguna iglesia del mundo. En el interior de la iglesia hay columnas de oro y plata e incontables lámparas de plata y oro. Alli hay un lugar (destinado a la) diversión del rey, adosado al muro del palacio, llamado Hipódromo. Cada año el rey organiza allí una grande diversión en el día de la Natividad de Jesús. En dicho lugar se exhiben, ante el rey y la reina, todo género de seres humanos que hay en el mundo, con todo tipo de encantamiento o sin él; y traen leones, panteras, osos y cebras para que luchen entre sí; hacen lo mismo con las aves y no se ve espectáculo como éste en ningún país» ${ }^{105}$.

En definitiva, el libro de viajes de Benjamín de Tudela ofrece al lector valiosísimas informaciones acerca de las regiones que recorrió y las ciudades que visitó, ya que en la mayor parte de los casos se trata de noticias absolutamente fidedignas; sólo en algunas ocasiones, cuando se trata de regiones que él no visitó personalmente -las tierras del Lejano Oriente-, parece haber sido demasiado crédulo ante las informaciones que se le facilitaron. Asimismo no dejan de ser interesantes las noticias que ofrece en relación con algunos grupos humanos marginales, como los guzz turcos, los fanáticos hasisín que luchaban contra los cruzados, los drusos de Siria, los alanos del Cáucaso, los armenios, los Valacos del valle del Danubio y los Balcanes, o los cusitas o etíopes del alto Nilo.

Desde el punto de vista geográfico, no son tampoco desdeñables las informaciones que Benjamín de Tudela transmite sobre la ubicación y las condiciones de ciudades y puertos, sobre los más diversos accidentes geográficos - mares, ríos, islas, montes-, y sobre la climatología de las regiones que atraviesa. Dice asi con relación al puerto de Quilón, al sur de la costa índica de Malabar:

"Desde Pésaj hasta Año Nuevo - todos los días del verano- nadie sale de su casa debido al calor, pues hace en ese país mucho calor, y desde las

105 Libro de Viajes de Benjamin de Tudela, pp. 66-67. 
tres del dia en adelante se esconden todos en sus casas hasta el atardecer, saliendo después. Encienden candelas en todos los zocos y plazas y luego, por la noche, realizan sus trabajos y transacciones, pues cambian noche por día debido al excesivo calor del sol» 106

Pero además del interés que la obra tiene en sí, un estilo literario marcado por la precisión en la descripción, por una narración lineal y sencilla y por un tono directo, casi podría decirse que coloquial, contribuye a una lectura ágil y amena. Las abundantes notas de carácter folclórico que se ofrecen al lector al hilo del relato enriquecen también de forma considerable la narración, y rompen la monotonía de los datos relativos a los personajes más destacados de las comunidades hebreas. Sirva de ejemplo la descripción que se hace acerca de las costumbres funerarias y religiosas de los habitantes de Quilón:

"Los hombres de aquel país no entierran a sus muertos, sino que los momifican con (ciertas) clases de bálsamos y los colocan en banquetas, cubriéndolos con sudarios. Todas las familias tienen casas donde colocan a sus antepasados y a sus familiares, secándose la carne sobre los huesos, aparentando talmente personas vivas. Todos reconocen a sus antepasados y familiares durante algunos años. Adoran al sol y tienen grandes templos en todas partes, a una distancia de media milla fuera de la ciudad. Por la mañana corren al encuentro del sol, pues en cada templo tienen un disco solar hecho con artificios de mago. Cuando sale sol, el disco da vuelta(s) con grandes ruidos y cada uno, hombres y mujeres, con su turíbulo en la mano, queman incienso al sol: tal es su camino de torpeza» ${ }^{107}$.

\section{CONCLUSIÓN}

A través de cuanto hasta aquí se ha expuesto, parece fuera de toda duda que los últimos decenios del siglo $x v$ y los primeros del $X V I$ marcan una restauración de la historiografía judía, después de varias centurias en las que la producción de contenido histórico quedó bastante postergada en la literatura hebrea. En este «renacimiento» del género historiográfico brillaron con luz propia diversos autores hispano-judíos o de origen hispano: Abraham ben Salomón de Torrutiel, Abraham Zacut, Rabí Yosef ben Saddiq de Arévalo, Seadyah ibn Danan, Salomón ben Verga y Yosef haKohén; también dentro del ámbito sefardí, no menos relevancia alcanzó el

106 Libro de viajes de Rabi Benjamin, p. 111.

107 Libro de viajes de Benjamín de Tudela, pp. 111-112. 
judeoportugués Samuel Usque, con su Conçolaçam as tribulaçoes de Israel (Ferrara, 1553).

Al margen del mundo hispano-judío, la aportación al género historiográfico fue también significativa en este momento en otros ámbitos europeos. Merecen ser destacados en el siglo XVI el cretense Eliyahu Capsali, quien redactó en el año 1523 su crónica titulada Seder Eliyahu Zutta (Crónica de la expulsión de Eliyahu), una historia del imperio otomano en la que intercala interesantes noticias acerca de las comunidades judías de diversas áreas geográficas, principalmente de España; la obra conocida como Sefer David ha-Reubeni (Libro de David de la Tribu de Rubén), redactada por autor desconocido entre los años 1522-1527, y que consiste en una crónica hagiográfica en la que los detalles maravillosos eclipsan a los elementos históricos; los italianos Gedallia ben Yosef ibn Yahyá de İmola, autor de una obra titulada Shalshelet ha-Qabbalah (Cadena de la Tradición, Venecia, 1586) en la que se revela como un gran compilador, y Azaryah min ha-Edomim de Rossi (1511-1578), autor en 1573 del Sefer Me'or enayim (Libro de la luminaria de los ojos), obra en la que se revela como un historiador propiamente renacentista por el uso que hace de las fuentes; $y$ el historiador y astrónomo alemán David Ganz (1541-1613), quien compuso en Praga una obra titulada Shemah David (Descendencia de David), que se compone de una crónica judía desde Adán hasta el año 1592, con listas de autoridades rabínicas y títulos de obras (sigue, en buena medida, a Abraham ben David y a Abraham Zacut), y una historia universal escrita utilizando crónicas generales, principalmente alemanas ${ }^{108}$.

Este renacer de la historiografía hebrea guarda estrecha relación con las difíciles circunstancias en las que se desarrolló la vida de las comunidades judías europeas en el período de tránsito entre la Edad Media y la Modernidad, momento en el que se multiplicaron las persecuciones antijudías, las órdenes expulsorias y las incautaciones de bienes de los hebreos en diferentes reinos y ciudades. En este contexto las crónicas hebreas, como expresan sus autores en términos siempre muy similares, pretendían fortalecer a la población judía en sus convicciones religiosas y mantenerla unida ante tan adversas circunstancias. Porque éste es, en definitiva, el objetivo que persiguen las obras que pueden ser encuadradas en el subgénero historiográfico que ha sido denominado "cadenas de transmisión de la tradición”: demostrar que la tradición judia se ha transmitido fielmente de generación en generación hasta el mismo momento en el que

108 Son interesantes las páginas que dedican a estos autores Alain BoYER y Maurice-Ruben HaYoun, L'historiographie juive, pp. 36-40 y 46-53. 
la crónica era redactada, con lo que no sólo se pretendía combatir a quienes negaban todo valor a la Ley oral, sino que, lo que era aún más importante, se buscaba reforzar a los fieles en la fe judía y en la obediencia a las autoridades rabínicas. Y otro tanto cabe decir de las obras pertenecientes al otro subgénero cultivado con mayor profusión en la literatura histórica judía de épocas medieval y moderna, en ocasiones denominado "historiografía lacrimosa"; así, mediante el relato de las persecuciones sufridas por el pueblo de Israel a través de la historia, los cronistas recordaban a sus correligionarios que también en otros tiempos se había pasado por circunstancias muy difíciles, que habían sido finalmente superadas, pero que para que para que ellos pudieran superarlas en ese momento era requisito impescindible la perseverancia en la fe y en las tradiciones judías y la práctica de las virtudes propias de los judíos de la Antigüedad: la fortaleza y la firmeza ante la adversidad, la constancia en la defensa de la fe, la unidad y la solidaridad.

Pero este florecimiento de la historiografía hebrea se diluyó pronto, de forma que a lo largo de los siglos XVII y XVIII la literatura de contenido histórico es escasa y de poca relevancia en el mundo judío ${ }^{109}$, hasta que tenga lugar un nuevo momento de esplendor a partir del siglo XIX.

109 Son dignos de miención, entre otros, Immanuel Aboab (1555-1628), de origen hispano, autor de una Nomologia, obra en la que revela amplios conocimientos lingüisticos, talmúdicos y cabalísticos, y en la que defiende al valor de la tradición oral y su necesidad para una correcta interpretación de la Torah; el italiano Yehudah Aryeh (o León) de Módena (Venecia, 1571-1648), autor de una obra autobiográfica titulada Hayye Yehudah (Vida de Judá); Nathan Neta Hannover (?-1683), autor de un libro titulado Yewen Metsula (El abismo profundo) (Venecia, 1653), en el que narra las masacres perpetradas contra los judios por el jefe de los cosacos entre 1648 y 1652 ; la alemana Glückel de Hameln (1645-1724), autora de unas Memorias que aportan datos interesantes acerca de la vida interna de la comunidad hebrea; y el lituano Yehiel Halperin (1660-1746), autor de un Seder ha-Dorot (El Orden de las Generaciones) (1769), que comprende una cronología de los hechos históricos más señalados desde la creación del mundo hasta ef año 1669, una presentación alfabética de la biografía de los tannaim y de los amoraim y una lista alfabética de libros hebraicos y de sus autores (Alain BOYER y Maurice-Ruben HaYoun, L'historiographie juive, pp. $40-46$ y $53-62)$. 